\title{
Energetic assessment of the agricultural production system. A review
}

\author{
Jean Hercher-Pasteur ${ }^{1,2}$ (D) Eleonore Loiseau ${ }^{1,2} \cdot$ Carole Sinfort $^{1,2} \cdot$ Arnaud Hélias $^{1,2}$
}

Accepted: 2 June 2020 / Published online: 23 July 2020

(C) INRAE and Springer-Verlag France SAS, part of Springer Nature 2020

\begin{abstract}
Energy holds a key role in farm systems. Cultivation is based on the conversion of solar energy into biomass of interest. Fossil energy allows mechanized and high-yield agricultural production system, but has a strong impact on climate change, and its supply is compromised in the next decades. Energy flows stand between two worlds: while energy is a strategic component of the economy, it is also a thermodynamic state variable for describing ecosystems. This situation reemphasizes the need for energy flow analysis in farm systems. There is a great variety in the approaches used to compute energy flows at farm scales. Yet, their main characteristics and the ways they handle farm sustainability issues need to be clarified. This review identifies ten kinds of energetic approaches, i.e., (i) conventional energy analysis, (ii) pluri-energy analysis, (iii) agroecological energy analysis, (iv) exergy analysis, (v) cumulative exergy consumption, (vi) extended exergy account, (vii) cumulative exergy extraction from the natural environment, (viii) eco-exergy, (ix) cosmic exergy analysis, and (x) emergy assessment. These approaches are analyzed through key features to discuss their ability to address resources' efficiency issues and identify promising outcomes for energy assessment of farms. This analysis emphasizes the lack of clear definition of system boundaries in farm-scale studies. In addition, most of the studies mainly focus on socio-economic flows through a sectoral perspective. Yet, internal biomass flows that play a role in maintaining agroecosystem functionality can also be considered according to a circular/systemic perspective. Then, integration of soil organic matter in the energy balance leads to significant changes in energy efficiency evaluation playing a function of biotic energy storage in the farm system. Hence, some recommendations are provided to perform an exhaustive energetic assessment of farm systems as well as future lines of research to be investigated.
\end{abstract}

Keywords Energy · Emergy · Exergy · Agricultural system · EROI (Energy Return On Energy Invest) · Agroecosystem · Circularity

\section{Contents}

1 Introduction

2 Protocol of the review

2.1 Literature review method

2.2 Key features to analyze energetic assessment approaches

3 Energetic approaches used to assess the agricultural system

3.1 Energy assessment

Jean Hercher-Pasteur

jean.hercher@supagro.fr

ITAP, Univ Montpellier, INRAE, Institut Agro, Montpellier, France

2 ELSA, Research Group for Environmental Life cycle and Sustainability Assessment, Montpellier, France
3.1.1 Approach \#1: conventional energy analysis

3.1.2 Approach \#2: pluri-energy analysis

3.1.3 Approach \#3: agroecological energy analysis

3.2 Exergy assessment

3.2.1 Approach \#4: exergy analysis and approach \#5: cumulative exergy consumption

3.2.2 Approach \#6: extended exergy account and approach \#7: CEENE

3.2.3 Approach \#8: eco-exergy and approach \#9: cosmic exergy analysis

3.3 Emergy assessment

4 Analysis of energetic approaches through the key features

4.1 Goal and scope of the reviewed studies

4.1.1 System scale

4.1.2 Aim of the study

4.1.3 Type of agricultural production

4.1.4 System modeling

4.2 Flow inventory 

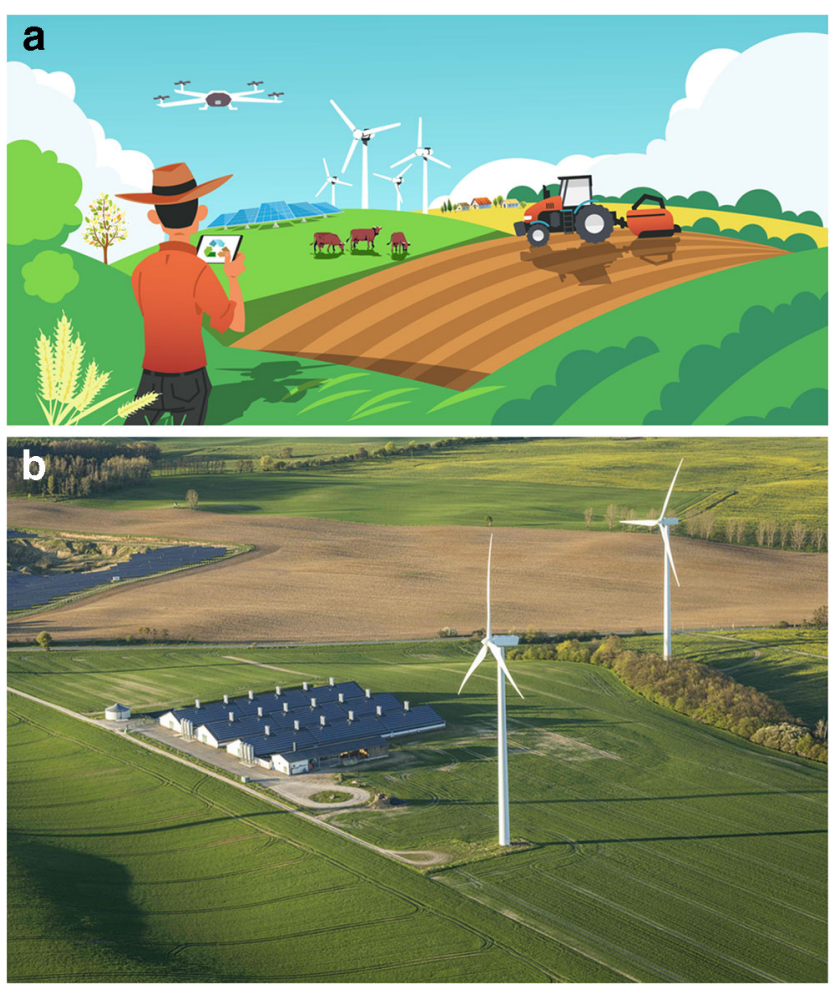

Fig. 1 a The farm system at a crossroad of different energetic flows. b The agricultural system at the interface between the different forms of energy production (biomass, electricity) and the different land uses (crop fields, hedges, forests, facilities, wind turbines, and photovoltaic fields)

\subsubsection{Primary natural resources}

4.2.2 Energy carrier, material, and products

4.2.3 Human labor

4.2.4 Internal flow

4.3 Energetic indicators

4.3.1 Energy use efficiency

4.3.2 Other energetic indicators

4.4 Implementation

5 Recommendations to conduct exhaustive energetic assessments

5.1 Specific semantic related to energy assessment

5.2 System boundary and the different energetic approaches

5.3 Consideration of internal flows

5.4 Ability of the approaches to address sustainability issues

6 Conclusion

Acknowledgments

References

\section{Introduction}

Since humans became sedentary, natural ecosystems were converted into agroecosystems in order to carry out and increase specific crop and livestock production. This provided an energy output from food and raw material, which was useful for human societies (Giampietro et al. 1992). In pre-industrial societies, agriculture was the major source of energy and materials (Aguilera et al. 2015), being what we call today a bio-based economy. Since the Industrial Revolution, agriculture increased its land and human productivity by substituting its energetic requirement with fossil fuels. Agriculture becomes less reliant on the variability of natural mechanisms (Gliessman 2006) but increasingly dependent on fossil fuels (Gupta and Hall 2011; Balogh et al. 2012; Krausmann 2016; Hall 2017). This is the turning point of our civilization from a solar economy to a mining economy (Wrigley 2013; Daviron 2016).

The modern agricultural system has presently reached a critical transition point in its performances (e.g., environmental impacts) (Tilman 1999; Tilman et al. 2002) as well as its energetics pattern (e.g., the entire food system requires roughly $10 \mathrm{kcal}$ of fossil energy to provide $1 \mathrm{kcal}$ of food) (IAASTD 2009; Bonny 2011; Pimentel et al. 2012; OCDE/FAO 2017; Gingrich and Krausmann 2018). Energy now appears to sit at the border between two worlds (Fig. 1), i.e., it is a strategic component of the economy (Han et al. 2019; TaghizadehHesary et al. 2019) as well as a thermodynamic state variable for ecosystems (Odum 1983).

Interest in agricultural energetic assessments began during the first oil crisis with the works of Pimentel $(1973,1976)$ and Odum (1973) in the 1970s. This attention declined during the 1980s when oil prices fell in 1986 (Risoud and Chopinet 1999). Since the 2000s, energy assessment has been receiving renewed attention in part due to interest in biofuel production efficiency (Tilman et al. 2009; Pelletier et al. 2011), the impact of greenhouse gas (GHG) emissions on climate (Stocker 2014), and the world fossil fuel peak production projected in 2025 (Mohr et al. 2015). This concern is expressed both by the amount of dedicated scientific papers (Vigne et al. 2012b) and by the variety of accounting methodologies (Pelletier et al. 2011). Energy analysis has been widely applied from farmscale to country-scale (Aguilera et al. 2015). It generally attempts to determine the energy cost of agricultural production. This method, initially used for assessing fossil-fuel dependency, has applications for comparing farming practices, organic and conventional farming, and recently biofuel production.

A number of existing reviews compile many energy analyses. Pelletier et al. (2011) described a general panorama of energy use in food systems with a life cycle perspective of food production. Zegada-Lizarazu et al. (2010) proposed a critical review of the energy balance of agricultural systems, highlighting the variability of the energetic value as well as the difficulty of defining a consistent system boundary. Smith et al. (2015) reviewed the energy efficiency of organic agriculture and compared it with conventional farming. They concluded that organic farming is more energy efficient than conventional farming, even though the productivity per unit of product is more variable. However, there is no exhaustive 
review of the energetic assessment approaches used to assess the agricultural production system.

The objectives of the present review are to identify the different energetic approaches applied to the agricultural production system, to analyze their main features and their ability to address resource efficiency issues, and to identify new lines of energy assessment promising field of investigation. It addresses farm- scale by repositioning them according to other scales (i.e., crop or regional scales). First, we define a protocol to select the existing literature and provide a critical analysis of the different energetic approaches identified through five key features. Secondly, we identify the main energetic approaches used to assess the agricultural production system. Then, we compare and analyze the different approaches through the key features. Finally, we discuss the issue of system boundaries and provide corresponding recommendations for future energetic approaches.

\section{Protocol of the review}

\subsection{Literature review method}

This literature review is based on the request [TITLE: ((ener* or exer* or emer*) and (agri* or farm* or agro* or "food production" or livestock) NOT (emerging or emergency or wind or wave or tide)) AND TOPIC: ((model* or balance or diagnostic or footprint or assessment or analysis))] used with "Web of Science", 10th of August 2018. It results in a selection of 1,192 papers. From this set, a first selection was carried out through the title and the abstract. Conference papers, articles without references (no DOI address), and papers out of scope were not considered. A first

Table 1 Key features and related criteria selected for the review

\begin{tabular}{ll}
\hline Key features & Related criteria \\
\hline (i) Goal and scope & System scale \\
& Aim of the study \\
& Type of agricultural production \\
(ii) System modeling & Representation \\
(iii) Flow inventory & Accounting process \\
& Primary natural resources \\
& Energy carrier \\
& Material and product \\
& Human labor \\
(iv) Indicators & Internal agroecosystem flow \\
& Energetic indicators \\
(v) Implementation & Other indicators \\
& Use of software \\
& Understandability \\
& Data availability \\
\hline
\end{tabular}

categorization was made according to the scale of the study (i.e., product scale, farm scale, national scale) and by identifying articles with contextual elements. A total of 196 papers covering the scope of the review were finally selected. Even though farm scales are the main interest here, articles from other scales highlighting methodological issues were integrated. They were then organized into a comparative table in order to identify common features and to compare the different approaches. Although the present review rather focuses on energy assessments at farm scales, different scales of analysis have been covered due to the different contexts of methodological aspects. While "Web of Science" requests revealed a general panorama, specific related articles that had not been included in the corpus were added to the review through the different references of the papers reviewed.

\subsection{Key features to analyze energetic assessment approaches}

The literature survey is analyzed through five key features, i.e., (i) goal and scope, (ii) system modeling, (iii) flow inventory, (iv) indicators, and (v) implementation. They are detailed in Table 1 and briefly presented as follows.

(i) First, depending on the goal and scope, the practitioner choses an appropriate energetic approach according to three main criteria i.e., i) system scale, ii) aim of the study and iii) type of agricultural production.

(ii) The choice of the approach has a direct influence on system modeling. It defines flow representation that is quantified within the system and between systems (Loiseau et al. 2012). In an energetic assessment, the agroecosystem is considered a unique system or represented with different subsystems. According to the model and to the relevance of the analysis, focus would be put on the ecosphere or technosphere flows. The ecosphere refers to the environmental mechanisms, whereas the technosphere is related to human activities (Jolliet et al. 2015). The agroecosystem is considered here a modified ecosystem by humans (Alhameid et al. 2017).

(iii) The type of energetic approach also determines the flows inventoried, i.e., (i) primary natural resources (i.e., sun, rain, wind, or geothermy) referring to the environment (i.e., ecosphere), (ii) energy carrier, and (iii) materials and products (fertilizers, raw materials, purchased seeds, forage, etc.) referring to the economic inputs (i.e., technosphere), (iv) human labor based on Fluck's classification (Fluck 1992) (i.e., muscular manpower, metabolized food energy, embodied energy of food consumed, and a lifestyle measure of labor, based on gross national production), and (e) internal flows onfarm (Tello et al. 2015) corresponding to the portion of 
biomass from the system and reinvested in the agroecosystem (vegetal biomass reuse, manure) but also animal power used for traction.

(iv) According to the system modeling and flows inventory, indicators are built. An indicator is defined as an "observed variable that is used to report a non-observable reality" (Boulanger 2004). Energetic indicators are directly related to energy assessment, such as EROI (Energy Return On Investment), energy productivity, energy intensity, net energy, or energy renewability index. Other indicators express the consequence of fossil energy use (e.g., carbon footprint) or are paralleled to the economic dimension of agricultural production systems. The different energetic indicators are presented in the supplementary material.

(v) Implementation refers to tools, data, or existing frameworks that is mobilized to perform studies. The existence of specific software for energy assessment may suggest that the method is widely used and has a good level of methodological maturity. Likewise, even though the understandability of a method remains a qualitative criterion, it is a key element for the usability, application, and adoption of the method by stakeholders.

\section{Energetic approaches used to assess the agricultural system}

Energetic assessment of agricultural production system can embrace different forms of energy account that follow the first and, in some cases, the second law of thermodynamics. Ten approaches are identified and are presented according to the energy accounting: (i) energy, (ii) exergy, and (iii) emergy.

\subsection{Energy assessment}

Energy assessment follows the first law of thermodynamics (i.e., the law of conservation). It has been defined as the process of determining the energy required directly and indirectly to allow a system to produce a determining product (or output) (IFIAS 1974). The approach is commonly assimilated to process analysis (Jones 1989) also known as bottom-up analysis (Murphy et al. 2011). Direct energy refers to the on-site energy used (e.g., fuel, electricity, gas, etc.). This corresponds to the heating value of the energy carrier consumed by the system (or process) but none of the energy requirements for prior steps (IFIAS 1978; Risoud 1999; Hülsbergen et al. 2001; Dalgaard et al. 2001; Pratibha et al. 2015). Murphy et al. (2011) define energy carriers as following: "It is a vector derived from a primary energy source (e.g., electricity, fuels, or wood fire)". Indirect energy (or off-site energy use) refers to the energy used to extract, transform, and transport the inputs to the system. (e.g., fertilizers, pesticides, machinery, fuels) (Aguilera et al. 2015). This corresponds to the energy embodied in the inputs, energy which is no more available as such (Hall 2017), also called the energy intensity of an input (Hall et al. 2011). The output represents the biomass production sold and is converted into energetic values. Energetic inputs and outputs are generally expressed in higher heating value,

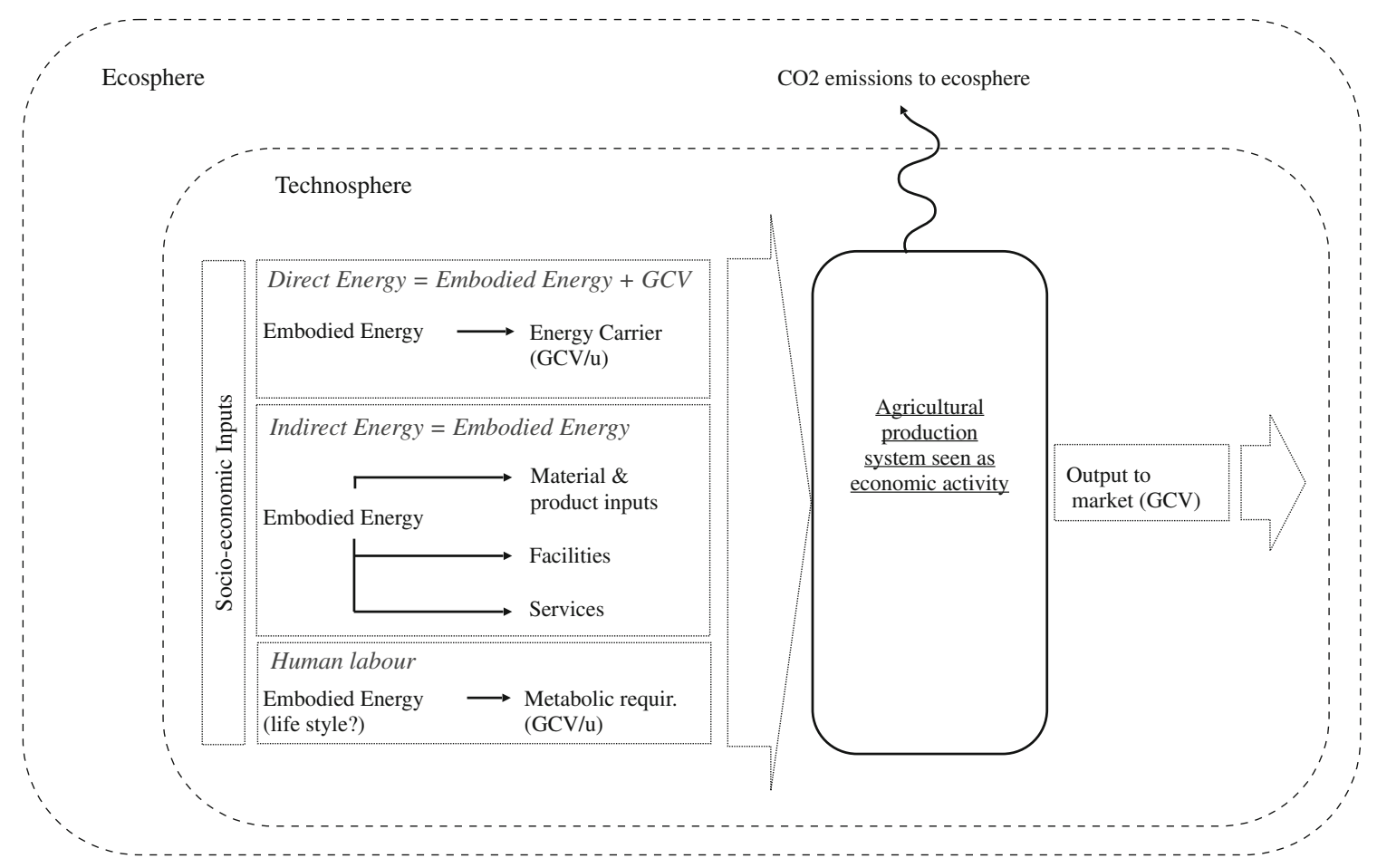

Fig. 2 Conventional energy analysis diagram placed within a strong sustainability vision 


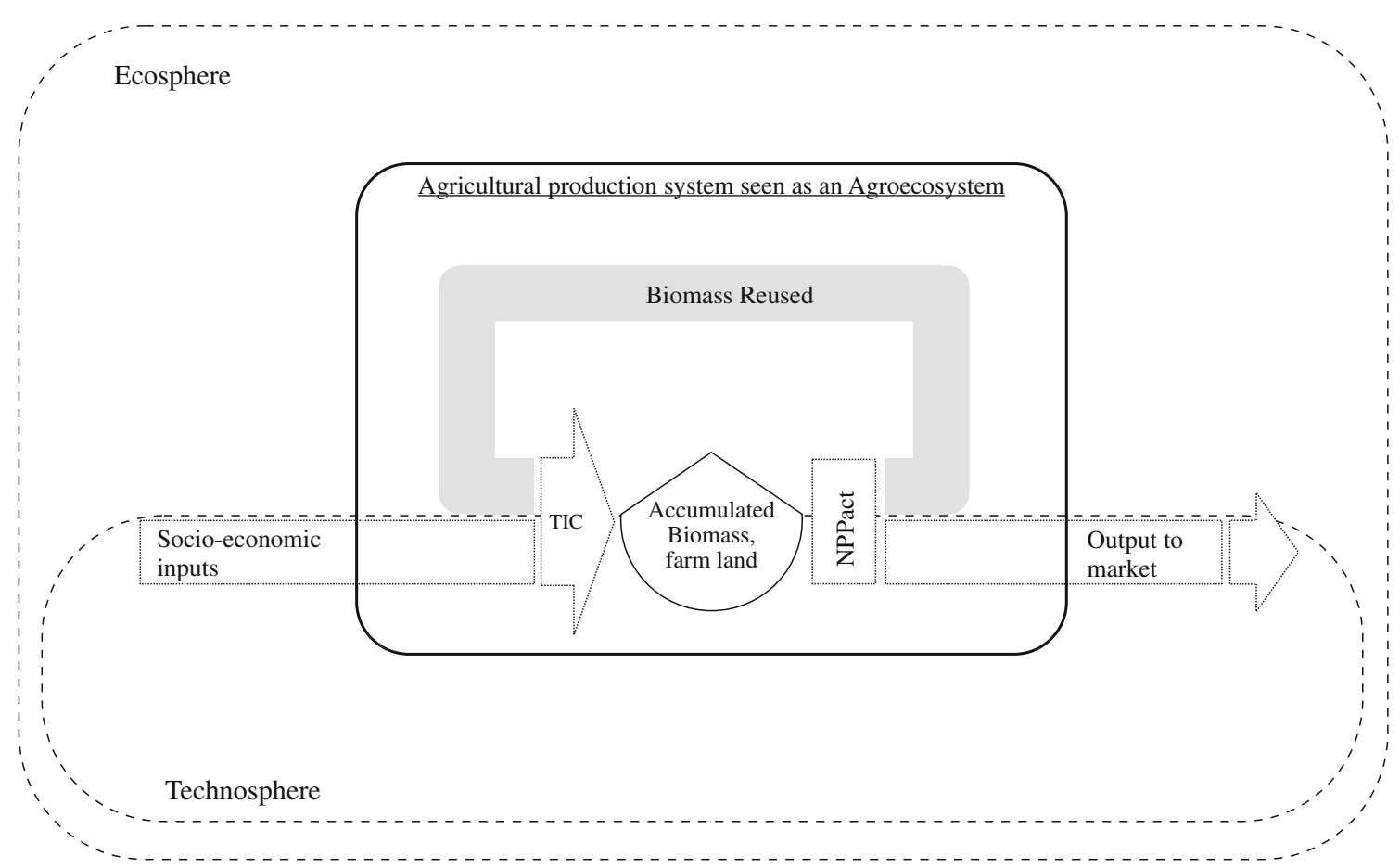

Fig. 3 Agroecological energy analysis diagram placed within a strong sustainability vision

also known as gross calorific value (GCV), and is defined as the amount of heat released once it is combusted.

\subsubsection{Approach \#1: conventional energy analysis}

Energetic analysis is the main method employed for assessing energy consumption and production (Fig. 6a)). In this group, conventional energy analysis (Fig. 2), also called net energy analysis or energy balance (Hall et al. 2011), is the most commonly applied (147 papers). Conventional energy analysis refers to works where the agricultural production system is considered a sector of the economy (sectoral approach) (Fig. 7), see as a unique system, and where the socioeconomic inputs and outputs are the main focus.

\subsubsection{Approach \#2: pluri-energy analysis}

Pluri-energy analysis framework proposed by Vigne et al. (2013b, 2014) is a first attempt to look energetic flows inside the agricultural system. This method aims at assessing the different types of energy mobilized and organized in agricultural systems, considering fossil energy, biomass (in gross energy), labor energy, and solar energy. The framework proposes to focus on the energetic account of internal flows, thus picturing the contrasting subsystems of mixed farming systems. A footprint approach has also been applied to the framework (Vigne et al. 2012b). They notice that it provides a good picture of the system but does not allow for a clear identification of energy efficiency possibilities. In another work, Arrieta et al. (2018) pointed some difficulties in allocating indirect land use change to footprint.

\subsubsection{Approach \#3: agroecological energy analysis}

After the conventional approach, agroecological energy analysis (AEA) is the most used energy assessment alternative (Fig. 3). It is defined by the developers as an agroecological perspective of energy analysis (Guzmán et al. 2014, 2015, 2017, 2018) and a bioeconomic accountancy of the energy flows and yields of farm system (Tello et al. 2016). AEA emphasizes in the role of internal biomass reinvested in the agroecosystem, looking at the farm system as part of the socio-ecosystem (i.e., systemic approach) (Fig. 7). It uses energy accounting for defining the socio-metabolism configuration between the agroecosystem and society (Tello et al. 2016; Marull et al. 2016; Galán et al. 2016; Tello and González de Molina 2017; Gingrich et al. 2018c; MacFadyen and Watson 2018; Fraňková and Cattaneo 2018; Guzmán et al. 2018; Cunfer et al. 2018; Parcerisas and Dupras 2018). Here, internal flow is considered an energy flow that is produced and used by the agroecosystem through the biomass unharvested, and the biomass harvested intentionally left in the agricultural production system.

\subsection{Exergy assessment}

Exergy follows the second law of thermodynamics. This means that all energetic processes are irreversible and produce a loss of energy called entropy (Szargut 2005). Exergy is the 


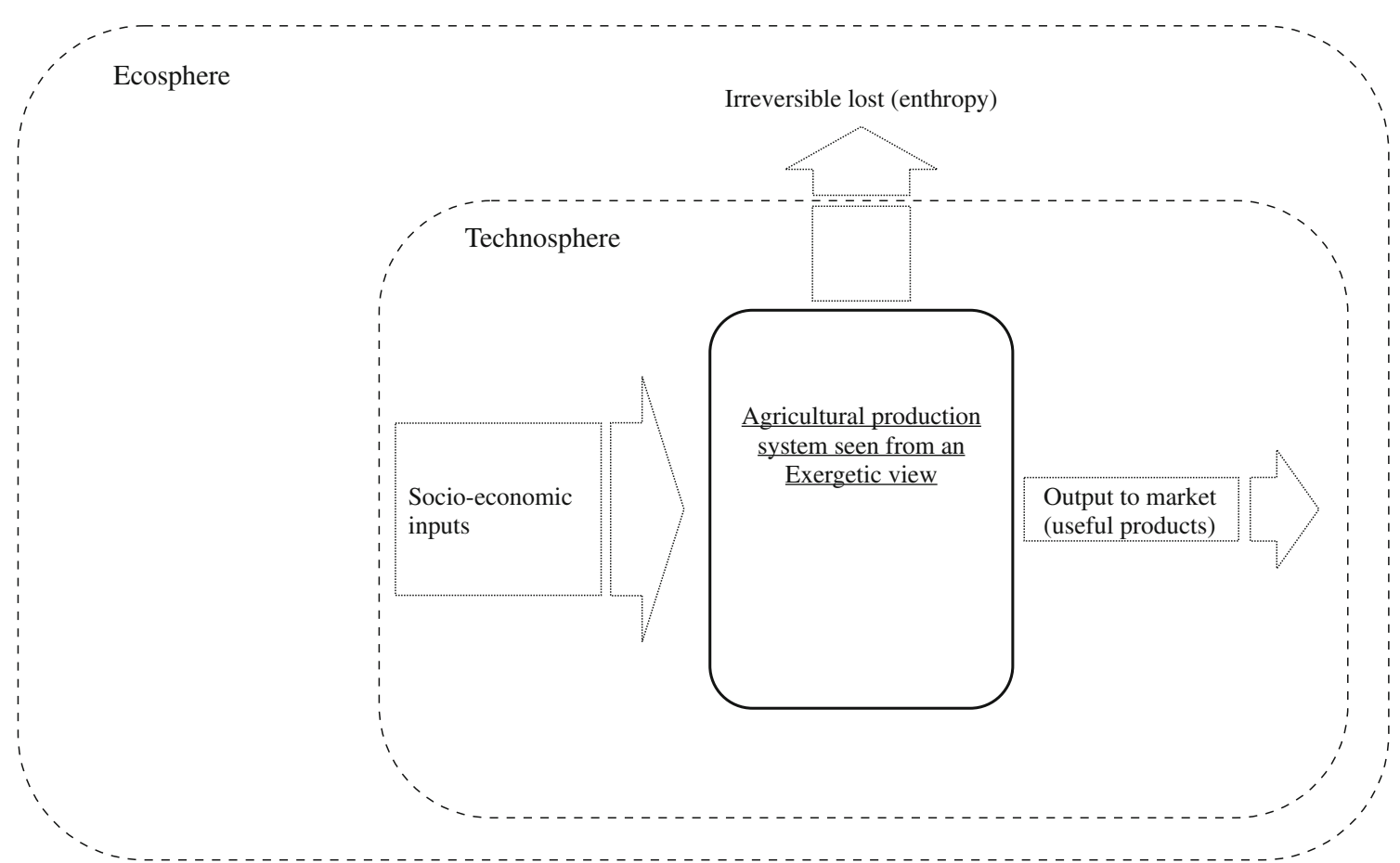

Fig. 4 Exergy assessment diagram placed within a strong sustainability vision

maximum amount of useful work that is obtained from a particular system or resource when it has reached equilibrium (Dewulf et al. 2008). Exergy measures both the quantity and the quality of energy (Hoang and Alauddin 2011). By quality, it means the ability of a certain energy source having certain amount of energy to cause change, i.e., the amount of energy which is extracted as useful (Dincer et al. 2005)

\subsubsection{Approach \#4: exergy analysis and approach \#5: cumulative exergy consumption}

Exergy analysis initially focused on specific consumption related to energy carriers (e.g., electricity for water pump or diesel consumption in tractors) to analyze the agricultural systems (Dincer et al. 2005; Utlu and Hepbasli 2006). It is concerned with the quality of energy to cause change, degradation of energy during a process, entropy generation, and lost opportunities to do work (Fig. 4). Cumulative exergy consumption $(\mathrm{CExC})$ extends exergy analysis beyond a single process to consider the exergy requirements of all the process and of its entire supply chain (Hoang and Alauddin 2011; Sciubba 2019). With the development of Life Cycle Assessment (LCA), the CExC is reinforced through the Cumulative Exergy Demand (CExD) (Hoang and Rao 2010) present in database such as Ecoinvent. Exergy assessment and CExC share the same interest of conventional energy assessment as they are concerned by socio-economic inputs. It is expected that exergy efficiency is usually lower than the energy efficiency, because the irreversibility of the process destroys some of the input exergy (Dincer et al. 2005). For example,
Huysveld et al. (2015) revealed that more than half of the resources consumed by dairy cows was irreversibly lost (through latent heating and transpiration). The remaining resources went to manure (54\%), methane emission (9\%), milk $(32 \%)$, and animal slaughter $(2 \%)$.

\subsubsection{Approach \#6: extended exergy account and approach \#7: CEENE}

Extended exergy accounting (EEA) involves, in addition to CExC, human labor, as well as capital and environmental impacts (Sciubba 2001, 2019; Amiri et al. 2020). The environmental impact is assimilated to a virtual environment input cost. Manso et al. (2017) tested three exergy accounting methodologies in the Portuguese agricultural, forestry ,and fisheries sectors, i.e., (i) energy resources exergy accounting (EREA), (ii) natural resources exergy accounting (NREA), and (iii) EEA. The first one considers the intrinsic exergy contained in the energy carrier; the second includes energy and matter. Manso et al. (2017) noted that the EEA results are dominated by capital and environmental impacts. Another identified approach is the Cumulative Exergy Extraction from the Natural Environment (CEENE) which was developed by Dewulf et al. (2007). This method quantifies eight categories of exergy "removed" from natural ecosystems, i.e., renewable resources, fossil fuels, nuclear energy, metal ores, minerals, water, land, and atmospheric resources. In their analysis, Hoang and Alauddin (2011) concluded that when EEA and CEENE were combined, the organic content in topsoil, feed, and total water withdrawal were the three main resources extracted from the environment. 


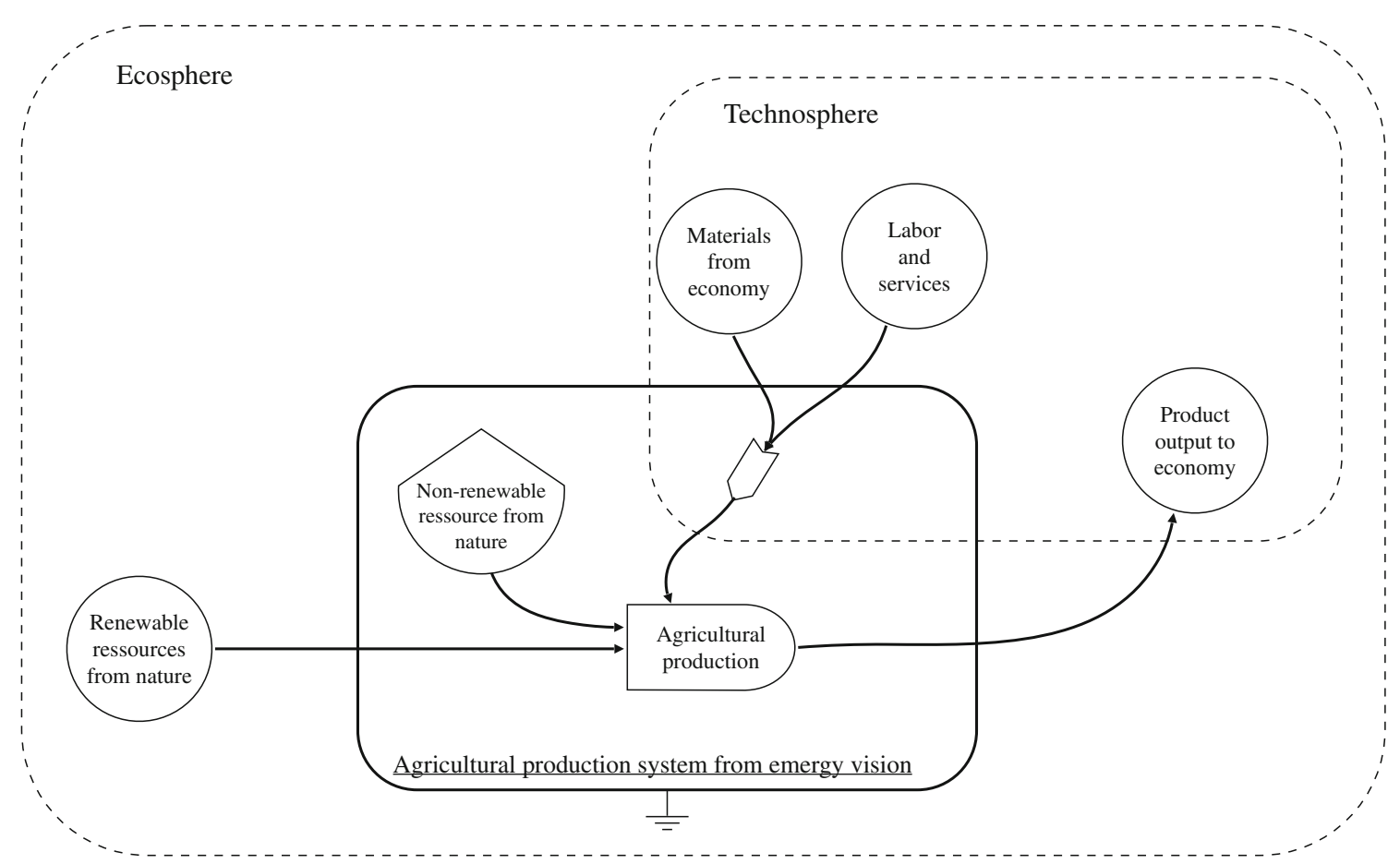

Fig. 5 Emergy assessment diagram placed within a strong sustainability vision

\subsubsection{Approach \#8: eco-exergy and approach \#9: cosmic exergy analysis}

Another exergetic accounting method identified in this review is eco-exergy developed by S.E. Jorgensen (2006). Ecoexergy is defined as the chemical exergy of an organism (its distance from chemical equilibrium) plus the exergy embodied in the (genetic) information. Perryman and Schramski (2015) proposed to combine EROI and eco-exergy ratios to evaluate both the quantity and quality of energy accumulated and dissipated in the agricultural processes of nine countries. The results reveal a correlation between these food production indicators and the ecological footprint (resources being consumed) of each country, while no correlation with their respective biocapacity was evidenced.

We also identify cosmic exergy analysis (Chen 2006). This approach mobilized embodied exergy to define Odum's Emergy (solar energy-based accounting, see the "Emergy assessment" section), resulting in a combined method placing exergy at planetary boundary scale (Chen et al. 2009, 2011). It has been applied to the farm system in order to compare three agroecosystem scenarios (i.e., farmland-biogas, farmlanddairy, farmland-dairy-biogas) (Liu et al. 2017). We have not developed this method any further in the manuscript.

\subsection{Emergy assessment}

Emergy is another form of accounting energy (approach \#10) (Fig. 5). It involves a more ecocentric vision that considers, in addition to the energies coming from the society, the energies from the natural flows (Zhang and Long 2010; Giannetti et al. 2011; Smith et al. 2015; Yi and Xiang 2016). Ecocentric vision implies that humankind is an equal part of nature and is associated with ecosystems (Abaidoo and Dickinson 2009). Initial development of emergy analysis began in the 1980s with the works of Odum $(1983,1984)$. However, it is only since 2006 that emergy assessment has been applied more commonly in agricultural systems (Diemont et al. 2006; Cavalett et al. 2006; Chen et al. 2006; Martin et al. 2006). Emergy represents all the energy used during the work processes that generate a product or service according to a lifecycle perspective. It is expressed with a common unit based on solar radiation (Brown and Ulgiati 2004). Solar Joule is the unit for measuring the energy required to generate a product weighted in solar energy. Some researchers consider emergy a sort of memory of solar energy that has been used (Pizzigallo et al. 2008). Emergy classifies inputs in four categories: (i) natural renewable resources (sun, rain, wind), (ii) natural non-renewable resources (e.g., soil organic matter or ground water), (iii) purchased non-renewable inputs (fossil fuels, fertilizers), and (iv) purchased renewable inputs (e.g., seeds, organic fertilizer) (Cavalett et al. 2006; Agostinho et al. 2008; Zhang et al. 2013; Rodríguez-Ortega et al. 2017).

Emergy is often presented as a complementary accounting method offering a global vision of energy dynamics where natural flows such as the sun, wind, or water are considered (Lu et al. 2010; Vigne et al. 2012b, 2013b; Kuczuk et al. 2017; Fan et al. 2018; Jafari et al. 2018). It can complement a standard socio-economic optimization model by adding a biophysical value to an agricultural system evaluation 


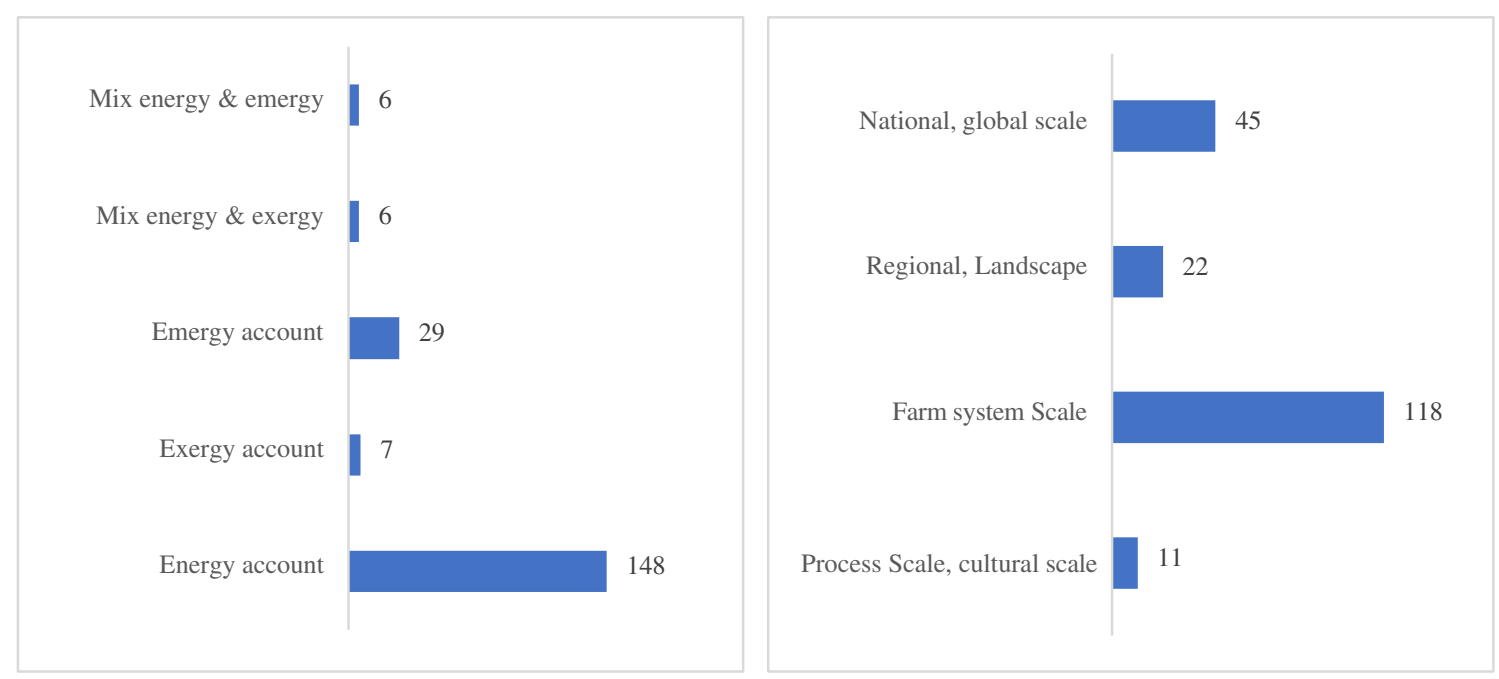

a) Metric used in the reviewed corpus

b) Spatial scale of the studies

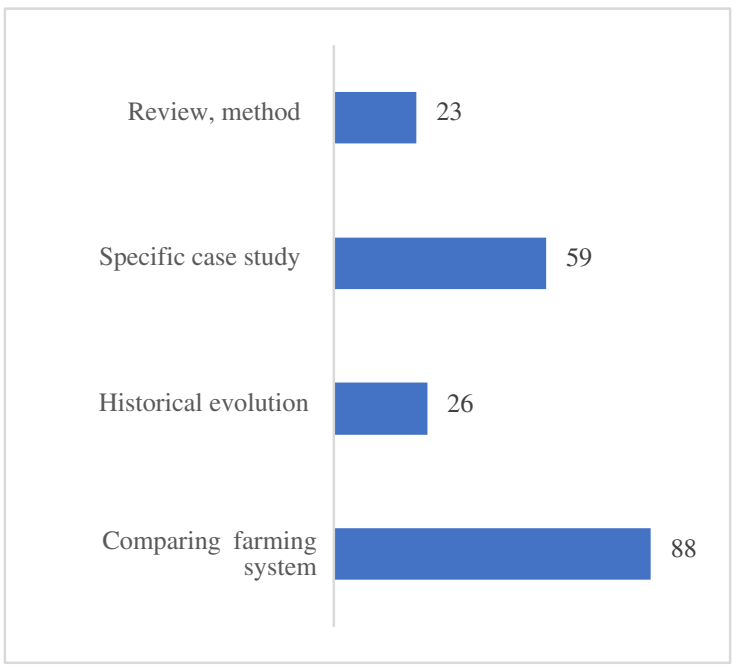

c) Type of studies used in the literature

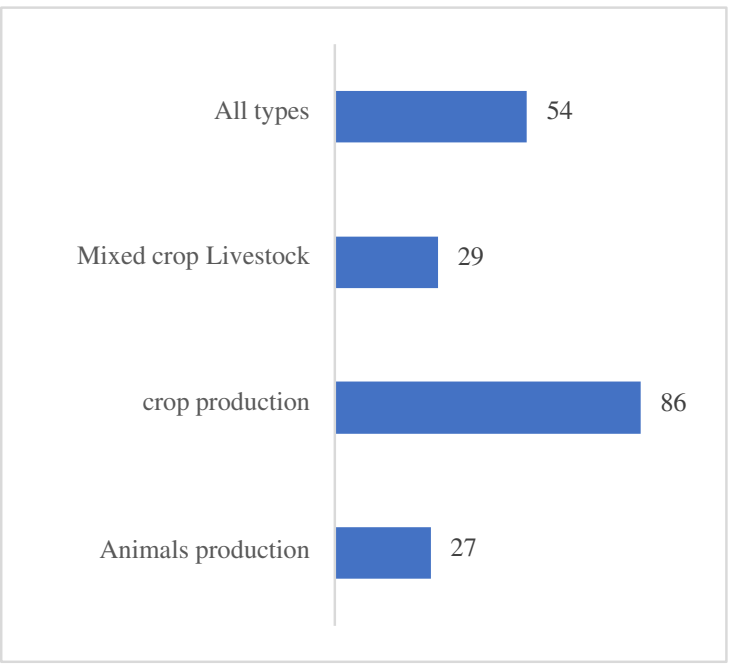

d) Type of agricultural production assessed in the literature

Fig. 6 Distribution of the 196 scientific literature reviewed from the "Web of Science" request through different criteria: (a) the metric used, (b) the spatial scale, (c) the type of studies, and (d) the type of agricultural production

(Kocjančič et al. 2018). In this case, emergy does not reflect the usefulness of a product but rather the cumulative environmental support for its existence. Emergy presents a relative homogeneity in its approach and in its accounting procedures.

\section{Analysis of energetic approaches through the key features}

\subsection{Goal and scope of the reviewed studies}

\subsubsection{System scale}

The majority of articles from the 196 papers selected in this review concerned farm system scales (Fig. 6b). Articles focusing on national and global scales were the second most important, followed by landscape or regional scales. Finally, only a few articles focused on the crop scale. Conventional energy analysis (used for all scales) is the only used energetic approach for comparing specific crop production (Fathollahi et al. 2018), studying agronomic approaches and technologies (Budzyński et al. 2015; Diacono et al. 2017; Arodudu et al. 2017; Fathollahi et al. 2018), or specific crop growth for bioenergy (Jankowski et al. 2016). Agroecological energy analysis is applied to regional and national scales (Gingrich et al. 2018b). Indeed, one goal of this approach is to explain landscape evolution and its relation with food system pattern (Padró et al. 2017; Cattaneo et al. 2018; Gingrich et al. 2018a). Exergy approaches are also mainly focused on regional and national scales (Utlu and Hepbasli 2006; Chen et al. 2009; 
Ghandoor and Jaber 2009; Ahamed et al. 2011) with one exception addressed at farm scale (Liu et al. 2017) and another two which were out of the "Web of Science" request (Huysveld et al. 2015; Amiri et al. 2020). Concerning emergy approach, the main scale is the farm system (24 from the 35 emergy studies reviewed).

\subsubsection{Aim of the study}

According to the type of study, the majority (45\%) of the papers focused on the comparison of farming systems (e.g., organic vs conventional or integrated vs conventional agricultures) (Bailey et al. 2003; Alonso and Guzmán 2010), farming practices (tillage vs non-tillage, different dairy housing system) (Alluvione et al. 2011; Uzal 2013), or comparing agricultural product energy efficiency (for food production or biofuels) (Pimentel and Patzek 2007; Fore et al. 2011; Elsoragaby et al. 2019). The second most important type of studies comprised specific case studies of agricultural system and production (30\%) studying particularly energy consumption (Bhatt and Bujarbaruah 2011; Migliorini et al. 2012; Pérez Neira et al. 2014; Clark et al. 2016; Bartzas and Komnitsas 2018). Indeed, conventional energy analysis, exergy, and CExC aim to analyze the direct and indirect energetic cost of agricultural production when emergy assessment looks at the global resources consumption, focusing on the sustainability of the farm system. EEA and CEENE also assess global resource consumption with a more anthropocentric interest using such as land resource use. Another set of articles focused on the historical evolution of energy use (Fig. 6c). If traditionally and presently conventional energy analysis is used to measure our increasing dependency on fossil energy, agroecological energy analysis is particularly dynamic in assessing historical evolution (Soto et al. 2016; Tello et al. 2016; Díez et al. 2018; Marco et al. 2018; Guzmán et al. 2018; InfanteAmate and Picado 2018; Harchaoui and Chatzimpiros 2019). Indeed, this approach assesses socio-metabolic and landscape evolution and configuration through its energetic framework enhancing energy return into the agroecosystem understudy.

Twenty-three articles were dedicated to review and methodological aspects. Three reviews of interest have been highlighted (Zegada-Lizarazu et al. 2010; Pelletier et al. 2011; Smith et al. 2015) (see introduction). A fourth review of Aguilera et al. (2015) (out of the request from "Web of Science") must be also mentioned and presents a deep research on the historical evolution of the embodied energy in agricultural inputs. Based on methodological aspects, Jones (1989) is often cited when referring to process analysis. Here, among others, an empirical classification of system boundaries is proposed, according to the method and scale of inventory (i.e., fossil fuel accounting, process analysis, ecosystem analysis method, and thermodynamic analysis). The methodological works of Guzmán et al. $(2015,2017)$ and Tello et al. (2016) must also be highlighted, where a socio-metabolic (Krausmann 2008, 2016; Gomiero 2017) energy profile of the agroecosystem is proposed.

\subsubsection{Type of agricultural production}

Regarding the type of agricultural production assessed, crop production for food or bioenergy is the main focus (Fig. 6d). Animal production and mixed crop livestock systems are similarly assessed.

\subsubsection{System modeling}

Energy assessment generally considers the farm as a unique system (75\% of the "Web of Science" request corpus) without any differentiation between production processes and environmental support functions (Tello et al., 2016). Subsystem representation allows for the presence of internal flows and process configuration. According to the subsystem representation, this can highlight major internal flows of biomass within the system (Tello et al. 2015). Vigne et al. (2013b) suggested the farm-scale system representation should be disassembled in order to compare contrasting dairy systems. The farm was thus divided into six generic subsystems, i.e., building and material, crop, vegetal production storage, livestock, manure storage, and family. Thanks to this method, significant differences in the configuration of energy flows between contrasting territories were revealed.

Tello et al. (2016) highlighted internal biomass reuse and its circularity aspects in the agroecosystem by representing three interconnected energy subsystems, i.e., livestock, farmland (composed of cropland, woodland, and pasture) and associated biodiversity. The agroecosystem was split into farmland and associated biodiversity (logical distribution in a farm operator's point of view), because each subsystem provides a different functionality (Tello et al. 2015). Farmland produces biomass for exportation while associated biodiversity ensures the regulation and support of ecosystem services.

A large part of emergy assessment is characterized by an energy system diagram, which is more (An et al. 1998) or less (Hu et al. 2012) complex and where other approaches such as LCA are associated (Wang et al. 2014, 2015). At the difference of the other resources, natural non-renewable resources, also called local non-renewable resources (i.e., soil organic matter (SOM) and ground water consumption), are represented inside the system as a storage system (diagram representation in supplementary material) (Wu et al. 2013; Jaklič et al. 2014; Jafari et al. 2018). Fan et al. (2018) proposed to reflect the dynamic of SOM storage in the agricultural production system by integrating SOM losses (i.e., already assessed in 
an emergy assessment), but also considering SOM gain as a co-product and accounted as an input.

Exergy papers do not depict farm subsystems as they are rather focused on accounting at national scales (Dincer et al. 2005; Utlu and Hepbasli 2006; Ghandoor and Jaber 2009; Ahamed et al. 2011) or at process scales (Zisopoulos et al. 2017). However, the study by Huysveld et al. (2015) (although out of the request) should be mentioned in subsystem farm representation. In this case study (i.e., specialized dairy farm in Flanders), an exergy assessment is first performed at process scale (the herd), revealing that more than half of the resources consumed by the herd is irreversibly lost. In a second step, an exergy analysis at farm scale with the CEENE method was carried out. It revealed that $93 \%$ of the total CEENE, in the case of a specific intensive dairy farm, is due to feed supply.

\subsection{Flow inventory}

\subsubsection{Primary natural resources}

Energy assessment does not take natural flows into account, such as sun radiation, wind, or water, as these are not produced by the socio-economic environment (technosphere) (Aguilera et al. 2015). With emergy analysis, these flows are considered through the amount of solar radiation accumulated in products and services. Nonetheless, the work of Bulatkin (2012) integrates natural resources while using Joule in its energetic accounting. The assessment is an attempt to allow for the different types of energy to be compared in terms of quality (Aguilera et al. 2015). Bulatkin (2012) proposed four categories of flows, i.e., solar radiation, organic matter and crop residue, energy of soil humus, and anthropogenic energy flows. Energy of soil humus is nicely represented through the energy lost during soil processes (i.e., soil mineralization).

Guzmán et al. (2015) propose to evaluate agroecosystem production in terms of Net Primary Production (NPP) (Guzmán et al. 2014), thus taking into account all biomass production in the system. Even if solar energy is not considered here (because it cannot be directly possessed or controlled by humans (Tello et al. 2015), NPP represents the true amount of energy incorporated into plant tissues (Guzmán et al. 2018) and, indirectly solar radiation.

\subsubsection{Energy carrier, material, and products}

Few studies clearly express energy carrier (e.g., fuels) both in terms of Gross Calorific Value (GCV) and in terms of embodied energy (Felten et al. 2013; Shamshirband et al. 2015). When information was lacking, the energetic value was used for distinguishing between a cumulative value (GCV plus embodied energy) and an enthalpy value (i.e., GCV). When

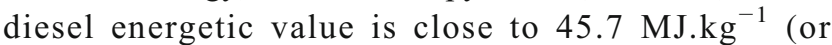

38.5 MJ.L ${ }^{-1}$ ) (Aguilera et al., 2015), the energy carrier is only considered in terms of GCV. Also, the use of direct and indirect terms to express inputs is a source of misunderstanding. Some consider that direct energy inputs correspond to the GCV plus the embodied energy of an energy carrier (Mendoza 2005) when others consider that direct energy corresponds only the GCV of an energy carrier (Shamshirband et al. 2015). This can lead to forgetfulness of the embodied energy of energy carriers in study that, on the one hand, considers embodied energy of materials and products (i.e., fertilizers, pesticides, machinery) without considering the embodied energy of e.g. diesel (Migliorini et al. 2012; Veiga et al. 2015; Lin et al. 2017). Using only the GCV for energy carriers (i.e., direct energy) is justified if the main objective of the study is to measure on-farm engines consumption.

In the case of materials and product inputs, embodied energy is generally taken into account from cradle to farm gate (Veysset et al. 2010; Pagani et al. 2016; Koesling et al. 2017). However, external biomass inputs such as seeds, manure, and organic matter are still not clearly described. In some cases, purchased seeds are accounted in terms of embodied energy (Kuesters and Lammel 1999; Ghorbani et al. 2011; Bos et al. 2014), while in other cases, it is the GCV of seeds that is taken into account (Rahman and Barmon 2012; Rahman et al. 2014; Rahman and Hasan 2014). In their comparison between organic and conventional Spanish farming systems, Alonso and Guzmán (2010) take into account both the cost of manufacturing and the energy content of the product (nutrient compositions) for chemical and mineral fertilizers. Pérez Neira et al. (2012) clearly presented manure inputs by only considering the energy content of the product when originating from the system itself as well as both GCV and embodied energy when purchased. In the case of materials and equipment, the energy required to produce them is depreciated according to a specific amortization method (Benoit and Laignel 2010) or more commonly uniformly distributed over the lifetime (total energy divided by years of useful life) (Alonso and Guzmán 2010).

\subsubsection{Human labor}

Measuring the energetics of human labor is highly controversial (Wu et al. 2011) and varies widely depending on system boundaries (Aguilera et al. 2015). The most notable works on the energy of human labor are probably the hierarchical Fluck (1992) review, the Jones (1989) thought process, the Aguilera et al. (2015) analysis, and also the work of Giampietro and Pimentel (1990). Many studies exclude human labor, particularly in industrialized systems, where it is marginal energetic value (Cleveland 1995; Maraseni et al. 2015). Still, without human labor, we would have no production. Others argue that it is too different from fossil energy to be expressed in the same units (Refsgaard et al. 1998; Hülsbergen et al. 2001). Metabolized food energy during work is the first energetic 
value used to describe human effort. It used generally

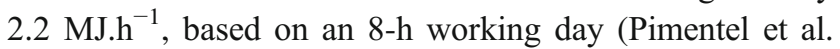
1973) in Western countries and $1.96 \mathrm{MJ}^{-1} \mathrm{~h}^{-1}$ in Middle Eastern countries (Singh et al. 1988; Gündoğmuş and $\mathrm{Gu}$ 2006; Mohammadi et al. 2014).

The last has been disapproved by $\mathrm{Wu}$ et al. (2011) who considered that by only accounting metabolic requirements, human labor is underestimated. The embodied energy related to production of food for laborers is mostly not accounted and can generate double counting issues (Aguilera et al. 2015). For the different manuscript based on agroecological energy analysis approach cited in this review, consumption baskets have been accounted from an embodied point of view considering site-specific data (by considering for example the energy embodied in transporting the food (Tello et al. 2015).

Sunshine Farm case study (Baum et al. 2009) also adopts an extended boundary for human labor. They applied net energy analysis for accounting human labor (Fluck 1981), including human lifestyle through input-output analysis, which was equivalent to $75 \mathrm{MJ}^{-1}{ }^{-1}$. Baum et al. (2009) also introduced the question of commuting energy in the farm system which could represent, following the formula of Patzek (2004), 34-54\% of the $75 \mathrm{MJ} / \mathrm{h}$ of labor. Later, Pimentel estimated the energy input for labor based on a yearly consumption of $8.000 \mathrm{~L}$ oil equivalent per person and 2000 working hours, representing 167.6 MJ.h ${ }^{-1}$ (Pimentel and Patzek 2007). Since transport is a large proportion of all the energy used in agriculture, this could be a good parameter to integrate, whether it is for the characterization of the embodied energy in food production or for the embodied energy in workers' displacement.

\subsubsection{Internal flow}

Consideration of internal flows is not recent, since an old article of the review dealing with on-farm circulating flows dates back to Han et al. (1985). In this study, they consider manure reuse within the system ( $70 \%$ of manure is collected and used in cropland), recycled outputs from crop production (e.g., seeds, seed cakes, and straw), human dejection, and reuse of biomass from non-cropland areas as green manure. Depending on the configuration between the farmers and the system, internal flows are also allocated to human nutrition. At a village community scale, Tripathi and Sah (2001) integrated the human component to the energy analysis of internal flows because humans were important consumers of the biomass production. More recently Harchaoui and Chatzimpiros (2019) emphasize in the importance to consider energy flows reinvested in food for humans and feed for draft animals (called "self-fueling") in order to measure trade-off between self-fueling and external inputs.

For Guzmán et al. (2015), internal flows refer to the flow of biomass reinvested in the system in order to keep the agroecosystem operational. The global biomass production is divided into biomass export (i.e., biomass sold), biomass reuse (i.e., harvested and reuse), unharvested biomass (i.e., roots principally), and accumulated biomass (in perennial plants). The configuration of this biomass flow characterizes and defines the capacity of the agroecosystem to generate flows of ecosystem services (Tello et al. 2016; Guzmán et al. 2018; Parcerisas and Dupras 2018).

In emergy, representation of internal flows is not necessarily detailed (Patrizi et al. 2018), but they are generally associated with a stock called in emergy "natural non-renewable

Table 2 Energetic indicators used in the literature with an anthropic consideration of the system

\begin{tabular}{|c|c|c|}
\hline Energetic indicators & Notes & References \\
\hline EROI $=\frac{\text { Energy output (sold) (MJ) }}{\text { Energy input (purchased) (MJ) }}$ & $\begin{array}{l}\text { This EROI refers to socio-economic input-output. It is equivalent to } \\
\text { other terms: energy (use) efficiency, input-output ratio, external } \\
\text { EROI }\end{array}$ & a) (See table note) \\
\hline Internal EROI $=\frac{\text { Energy output }(\mathrm{MJ})}{\text { Biomass reuse }(\mathrm{MJ})}$ & $\begin{array}{l}\text { Refers to the efficiency of internal biomass intentionally return into } \\
\text { the system }\end{array}$ & b) (See table note) \\
\hline$F$ inal EROI $=\frac{\text { Energy output }(\mathrm{MJ})}{\text { External input }+ \text { Biomass reuse }(\mathrm{MJ})}$ & $\begin{array}{l}\text { Biomass reuse refers to harvested crop residue and reused } \\
\text { intentionally in the system }\end{array}$ & b) (See table note) \\
\hline Non-renewable EROI $=\frac{\text { Energy output }(\mathrm{MJ})}{\text { Non-renewable external input (MJ) }}$ & & c) (See table note) \\
\hline Fossil energy efficiency $=\frac{\text { Energy output }(\mathrm{MJ})}{\text { fosSil energy direct and indirect input (MJ) }}$ & & $\begin{array}{l}\text { (Mendoza 2005; } \\
\text { Vigne et al. } \\
\text { 2013b) }\end{array}$ \\
\hline Gross energy efficiency $=\frac{\text { Energy output (MJ) }}{\text { External biomass input (MJ) }}$ & Consider the gross calorific value of the external biomass consumed & $\begin{array}{l}\text { (Vigne et al. } \\
\text { 2013b) }\end{array}$ \\
\hline Labor energy efficiency $=\frac{\text { Energy output }(\mathrm{MJ})}{\text { Human labor (metabolic value)(MJ) }}$ & $\begin{array}{l}\text { Adapt to local conditions and activities with a stress score value from } \\
1 \text { (driving) to } 5 \text { (plowing) }\end{array}$ & $\begin{array}{l}\text { (Vigne et al. } \\
\text { 2013b) }\end{array}$ \\
\hline Solar energy efficiency $=\frac{\text { Energy output }(\mathrm{MJ})}{\text { Photosyntetic active radiation (MJ) }}$ & & $\begin{array}{l}\text { (Vigne et al. } \\
\text { 2013b) }\end{array}$ \\
\hline
\end{tabular}


Table 3 Energetic indicators used in the literature with an agroecological consideration of the system

\begin{tabular}{|c|c|c|}
\hline Energetic indicators & Notes & References \\
\hline Agroecological final EROI $=\frac{\text { Energy output (MJ) }}{\text { Biomass reuse }+ \text { external input }+ \text { unharvested biomass (MJ) }}$ & $\begin{array}{l}\text { Energy expressly invested in } \\
\text { the system and the recycled } \\
\text { without human intervention }\end{array}$ & $\begin{array}{r}\text { (Guzmán et al. } \\
2015,2018)\end{array}$ \\
\hline $\mathrm{NPPact}$ EROI $=\frac{\mathrm{NPPact}(\mathrm{MJ})}{\text { Biomass reuse }+ \text { external input }+ \text { unharvested biomass (MJ) }}$ & $\begin{array}{l}\text { NPPact is the amount of energy } \\
\text { actually incorporated into all } \\
\text { plant tissues }\end{array}$ & $\begin{array}{l}\text { (Guzmán et al. } \\
\text { 2015, 2018; } \\
\text { Galán et al. } \\
\text { 2016) }\end{array}$ \\
\hline Biodiversity EROI $=\frac{\text { Unharvested biomass }(\mathrm{MJ})}{\text { Biomass reuse }+ \text { external input }+ \text { unharvested biomass (MJ) }}$ & $\begin{array}{l}0 \text { means all biomass is reused. } 1 \\
\text { means natural ecosystem } \\
\text { without human intervention }\end{array}$ & $\begin{array}{l}\text { (Guzmán et al. } \\
\text { 2018) }\end{array}$ \\
\hline Woodening EROI $=\frac{\text { Accumulated biomass }(\mathrm{MJ})}{\text { Biomass reuse }+ \text { external input }+ \text { unharvested biomass (MJ) }}$ & $\begin{array}{l}\text { Informs whether the energy } \\
\text { added to the system } \\
\text { contributes to the storage of } \\
\text { energy in the system }\end{array}$ & $\begin{array}{l}\text { (Guzmán et al. } \\
\text { 2018) }\end{array}$ \\
\hline Environmental efficiency of support energy $=\frac{\text { Energy output }+\Delta \mathrm{SOM}(\mathrm{MJ})}{\text { Energy input }(\mathrm{MJ})}$ & $\begin{array}{l}\text { This indicator aims at } \\
\text { evaluating system efficiency } \\
\text { by using supporting energy }\end{array}$ & $\begin{array}{l}\text { (Alluvione } \\
\text { et al. 2011) }\end{array}$ \\
\hline Input - output ratio $\Delta \mathrm{SOC}=\frac{\text { Energy output }+\Delta \mathrm{SOC}(\mathrm{MJ})}{\text { Energy input }(\mathrm{MJ})}, \Delta \mathrm{SOC}>0 ;=\frac{\text { Energy output }(\mathrm{MJ})}{\text { Energy input }+\Delta \mathrm{SOC}(\mathrm{MJ})}, \Delta \mathrm{SOC}<0$ & $\begin{array}{l}\text { Considering variation of soil } \\
\text { organic matter }\end{array}$ & $\begin{array}{l}\text { (Fan et al. } \\
\text { 2018) }\end{array}$ \\
\hline Indicator of immediate removal $=\frac{\text { Biomass harvested }(\mathrm{MJ})}{\text { EUnharvested biomass(MJ) }}$ & $\begin{array}{l}\text { Determine cropping system } \\
\text { orientation as } \\
\text { market-focused or soil } \\
\text { fertility-focused }\end{array}$ & $\begin{array}{l}\text { (Alluvione } \\
\text { et al. 2011) }\end{array}$ \\
\hline Edible energy efficiency $=\frac{\text { Edible energy output }(\mathrm{MJ})}{\text { EUnharvested biomass(MJ) }}$ & & $\begin{array}{l}\text { (Galán et al. } \\
\text { 2016) }\end{array}$ \\
\hline
\end{tabular}

resources" (Cavalett et al. 2006; La Rosa et al. 2008) (i.e., soil organic matter, ground water). In other emergy study, the portion of the biomass production reinvested into the system has clearly been expressed (Diemont et al. 2006; Jafari et al. 2018). However, in the case of emergy, due to the background notion of cumulative energy, the risk of double counting remains a point of awareness (Patrizi et al. 2018).

Actually, soil organic matter is defined as the solar energy stored in the farm system (Jordan 2016). Its renewability will depend on how we take care of this resource and is defined as a fund resource (Tello et al. 2015). At the difference of stock resource (based on the consumption of a declining resource), a fund resource is defined by a given rate of flow production (Georgescu-Roegen 1971; Giampietro et al. 1992). This notion is a key element in understanding the interest of assessing internal flows and its role played in maintaining agroecosystem function.

\subsection{Energetic indicators}

\subsubsection{Energy use efficiency}

Energy use efficiency, commonly called Energy Return On energy Invest (EROI) is the ratio between output and input (all

Table 4 Other energetic indicators used in the literature

\begin{tabular}{|c|c|c|}
\hline Energetic indicators & Notes & References \\
\hline Specific energy input $=\frac{\text { Energy input }(\mathrm{MJ})}{\text { Crop yield }(\mathrm{kg})}$ & $\begin{array}{l}\text { Amount of energy used to produce one } \mathrm{kg} \text { of } \\
\text { product }\end{array}$ & a) (See table note) \\
\hline Energy productivity $=\frac{\text { Crop yield }(\mathrm{kg})}{\text { Energy input }(\mathrm{MJ})}$ & $\begin{array}{l}\text { Amount of product obtain per unit of energy } \\
\text { input }\end{array}$ & b) (See table note) \\
\hline Net energy gain $=$ energy output - energy input & & c) (See table note) \\
\hline Energy intensiveness $=\frac{\text { Energy input }(\mathrm{MJ})}{\text { Total cost }()}$ & & $\begin{array}{l}\text { (Zangeneh et al. 2010; Choudhary } \\
\text { et al. 2017) }\end{array}$ \\
\hline Energy intensity $=\frac{\text { Energy input }(\mathrm{MJ})}{\text { Energy output }(\mathrm{MJ})}$ & & (Koesling et al. 2017) \\
\hline Energy productivity per labor unit $=\frac{\text { Energy output }(\mathrm{MJ})}{\text { Labor unit }(\mathrm{h})}$ & & (Choudhary et al. 2017) \\
\hline $\begin{array}{r}\text { Net environmental energy }=\text { Energy } \\
\text { output }+\Delta \mathrm{SOM}-\text { energy input }\end{array}$ & & (Alluvione et al. 2011) \\
\hline
\end{tabular}


the indicators cited are in the supplementary material) (Hall et al. 2009; Hall 2017). Present in 75\% of the 196 papers from the "Web of Science" request, it is the most commonly used energetic indicator and concerns principally purchased inputs (also called external inputs) and outputs sold (Table 2). Variability in system boundaries makes difficult comparing energy efficiency between systems. In order to reinforce exhaustiveness but also to avoid confusion in the type of energy inputs, Pérez Neira et al. (2018) propose to specify energy inputs in terms of cumulative energy demand used in LCA.

In the case of agroecological energy analysis, Guzmán et al. (2015) and Tello et al. (2016) consider that one EROI is not enough and suggest three different EROIs (i.e., external final EROI, final EROI, and internal final EROI). Guzmán et al. (2015) go further suggesting EROI from an agroecological point of view (Table 3 ), integrating all the biomass produce of the agroecosystem and not just the part that is sold (e.g., NPPactEROI).

In the same direction of integrating agroecosystem elements in the EROI, two energetic assessments suggest the integration of soil organic matter variation $(\triangle \mathrm{SOM})$ into the EROI (Alluvione et al. 2011; Fan et al. 2018). If there is a loss of SOM, it is considered an output and added to the other outputs of the system (i.e., as a nominator) (Alluvione et al. 2011; Fan et al. 2018). Fan et al. (2018) go further by considering SOM an input (i.e., as a denominator) if there is a gain in SOM. Soil loss and decrease of SOM remain important issues in present-day agricultural practices that affect crop yield, physical soil properties, fertility, and water-holding capacity (Pimentel et al. 2012). Fan et al. (2018) observations suggest that soil loss and SOM decrease produce a stronger influence on EROI than mineral fertilization. Indeed, in its study, the crop rotation (i.e., fallow-wheat-pea, with a low input strategy and no tillage) that showed the best EROI (12.9), falls to near the worst crop rotation trial (EROI, 3.7) when integrating SOM decrease.

a) (Mrini et al. 2002; Singh et al. 2002; Jianbo 2006; Baum et al. 2009; Hall et al. 2011; Alluvione et al. 2011; Ramedani et al. 2011; Rahman and Barmon 2012; Soni et al. 2013; Firrisa et al. 2014; Sefeedpari et al. 2014b; Atlason et al. 2015; Guzmán et al. 2015; Tello et al. 2016; Choudhary et al. 2017; Parcerisas and Dupras 2018; Pérez Neira et al. 2018; Bartzas and Komnitsas 2018)

b) (Guzmán et al. 2015, 2018; Tello et al. 2016; Galán et al. 2016; Parcerisas and Dupras 2018)

c) (Alonso and Guzmán 2010; de Muner et al., 2015; Pérez Neira 2016; Pérez Neira et al. 2018)

\subsubsection{Other energetic indicators}

Energy intensity represents the embodied energy per output. A majority of articles use the term "specific energy input" when analyzing energetic consumption (both direct and indirect) per unit of product. Energy intensity should not be mistaken with the term "energy intensiveness" employed in other articles (Zangeneh et al. 2010; Choudhary et al. 2017) representing the cost of energy inputs consumed as a fraction of the total inputs (Table 4).

Energy productivity (unit.MJ ${ }^{-1}$ ) and net energy (output input) are also common energetic indicators found in the literature. Energy productivity was more frequently used in crop production topics (Jekayinfa et al. 2012; Sefeedpari et al. 2014a; Choudhary et al. 2017; Bartzas and Komnitsas 2018).

Concerning renewability ratio (i.e., renewable/non-renewable), even if it is principally in emergy account that we met this indicator, for certain energetic analysis, particularly in Middle Eastern countries, a clear differentiation between non-renewable and renewable inputs is generally made (Beheshti Tabar et al. 2010; Pishgar-Komleh et al. 2012; Mohammadi et al. 2014; Choudhary et al. 2017).

a) (Singh et al. 2004; Ramedani et al. 2011; Rahman and Barmon 2012; Jekayinfa et al. 2012, 2013; Sefeedpari et al. 2013, 2014b; Pagani et al. 2016; Bartzas and Komnitsas 2018)

b) (Rahman and Barmon 2012; Jekayinfa et al. 2012; Sefeedpari et al. 2014b; Choudhary et al. 2017; Bartzas and Komnitsas 2018)

c) (Rahman and Barmon 2012; Jekayinfa et al. 2012; Sefeedpari et al. 2014b; Arodudu et al. 2016)

\subsection{Implementation}

In the corpus of reviewed articles, seven articles were identified for their use of a specific software to calculate energy flows in agricultural systems. Chen and Baillie (2009) assessed the use of on-farm operational energy (direct energy) for cotton production using the EnergyCalc software. Another computer tool identified in 3 papers (Veysset et al. 2010; Benoit and Laignel 2010; Vigne et al. 2014) is the Planet method developed by Risoud (1999) and Bochu (2006). Planet calculates the energy balance and performs an efficiency analysis considering essentially fossil fuels and electricity that are directly and indirectly consumed by the system (Benoit and Laignel 2010). Kraatz (2012) also employed the modeling software called REPRO (Reproduction of Soil Fertility) to analyze the farming system and to evaluate energy intensity in livestock operations. FEAT (Farm Energy Analysis Tool) is an open-source database model developed by Camargo et al. (2013) in an attempt to unify approaches, interfaces, and sourcing data. It calculates energy use and GHG emissions. Finally, Fathollahi et al. (2018) performed an energy, economic, and environmental analysis of forage production systems using SimaPro 8.3.0. They thus produced a complete energetic analysis combined with a LCA.

Understandability is a qualitative criterion in the present review and must be interpreted with caution as it is relatively 
subjective. Nevertheless, the majority of emergy and exergy assessments were classified in the "difficult" category. This is partly because emergy and exergy methods are based on the second law of thermodynamics.

The majority of the energetic value was obtained from the literature with a large range of variability (Zegada-Lizarazu et al. 2010; Vigne et al. 2012a). Some papers use general databases such as Ecoinvent (Upton et al. 2013; Blancard and Martin 2014; Barak et al. 2016; Ghisellini et al. 2016; Pishgar-Komleh et al. 2017; Koesling et al. 2017; Pragya et al. 2017; Todde et al. 2018a). However, precision also requires that energetic values adapt to local conditions (Alonso and Guzmán 2010; Vigne et al. 2012a, 2013a) (e.g., machinery production, electric matrix, fossil energy, or human labor). Transport of input, such as biomass (feed, organic matter, etc.) used on-farm, was usually the major adjustment made (Guzmán et al. 2018; Pérez Neira et al. 2018). Concerning emergy, a general database with transformity values (i.e., solar joule per unit of joule) is not yet available, which can lead to higher variability in energetic value (Amaral et al. 2016).

\section{Recommendations to conduct exhaustive energetic assessments}

\subsection{Specific semantic related to energy assessment}

A large part of this review concerns system boundary definition, which remains a particular point of frailty in the energy assessments. The selection of an appropriate system boundary for energy analysis and for applying indicators such as EROI is a crucial step which is often overlooked (Murphy et al. 2011). Thus, a first step for a clear and coherent system boundary will be related to the semantic mobilized. Nonhomogenized semantics and the vocabulary result from the plurality of approaches. However, it also reflects variability in the system boundary and limits the exhaustiveness in the flow inventory.

The distinction of inputs in "direct" and "indirect" still remains a source of misunderstanding (see the "Other energetic indicators" section). We chose to define direct as the GCV of an energy carrier as it is useful for engineering purpose (i.e., the energy required in a process) (IFIAS 1978). Embodied energy also has different definitions. Some studies characterize embodied energy as the higher heating value (gross energy) of the input, plus the energy requirements for the production and delivery of the input (Aguilera et al. 2015; Koesling et al. 2017). This would represent the equivalent of the Cumulative Energy Demand (CED) used in LCA. In this review, we chose to follow the definition of Hall (2017): "Embodied energy is the energy once used to make something and is no longer able to do work". If this definition were applied to the diesel used on the farm, this would be equivalent to the energy used for its extraction, process, and transport, therefore equal to $9.1 \mathrm{MJ}^{\mathrm{L}} \mathrm{L}^{-1}$ (Zegada-Lizarazu et al. 2010).

If the study bases its methodology in a "process analysis," also defined as a partial LCA (i.e., only energetic flow considered) (Pérez Neira et al. 2014; Todde et al. 2018b), whatever how we classify inputs in "direct and indirect", external inputs must be accounted in terms of GCV and embodied energy, which is equivalent to the CED in LCA. Even though process scales and a cradle to farm gate are generally applied, differences prevail in the input inventory and subsequently in the system boundary too. Since the development of LCA (i.e., reinforcement of its application and ISO formalization), the methodology of energy accounting through a process analysis method has also been improved. An LCI (Life Cycle Inventory) protocol offers exhaustiveness in process flow inventory and is often cited as the methodological choice for energy assessment (Fredriksson et al. 2006; Arodudu et al. 2016; Pryor et al. 2017; Fathollahi et al. 2018).

\subsection{System boundary and the different energetic approaches}

The aim of the study and associated energetic approach drives the system boundary. Conventional energy analysis is focused on the socio-economic environment, i.e., how much energy has been purchased and how much has been sold. Energy assessment is frequently regarded as a benefit-cost evaluation (Zangeneh et al. 2010; Pishgar-Komleh et al. 2011, 2017; Jekayinfa et al. 2013). Emergy and some exergy approaches, by the nature of their thermodynamic accounting process, by considering sun radiation the master flow, can argue to be at planet boundary. These latter two energy accounts have convinced a growing community of researchers, offering a global energy assessment and highlight the energy loss of a system (i.e., entropy). Their objective is generally to assess environmental sustainability. The conventional energy assessment deserves to be more in line with our economic model and to provide more direct answers to the farming community. A better consideration of the ecosphere is a tendency that has been observed in energy assessment thanks to the development of circular approach and to the consideration of internal biomass production, thus highlighting its role in preserving agroecosystem functions (Tello et al. 2016). Nevertheless, when the energy analysis requires a better clarity in system definition, the integration of internal inputs could become an issue for the flow inventory and might open up the necessity to deal with different EROI (Guzmán et al. 2015).

Murphy et al. (2011) highlighted this issue for EROI analysis. In a production process, they organized flow inventory in increasing levels of analysis by widening the system boundary to include more inputs: (i) level 1 is the internal energy consumption; (ii) level 2, the external energy consumption; (iii) 
level 3, the materials consumption, (iv) level 4, the labor consumption; and (v) level 5, the auxiliary service consumption. Pérez Neira et al. $(2012,2014)$ suggested an approach similar in agricultural context. They organized the flow inventory through four categories ("level" was the word used): (1) direct energy, (2) material and energy cost of production (embodied energy), (3) fixed capital, and (4) energy in maintaining the fixed capital.

We translate the approach of Murphy to the agricultural farming system by expansion of the system boundary to include more inputs: the first level corresponds to an internal flow of biomass reuse within the farm system. This first category of energetic flows leads to use the agroecological energy analysis approach. As the farm system is at the frontier between ecosphere and technosphere, and human management mobilizing tools and machines, the next levels ( 2 and 3 ) correspond to the cumulative energy demand of external inputs, mobilizing EROI from a socio-economic interest. This category of energetic flows is assessed easily with conventional energy assessment through an energetic LCI. There is still debate on how to incorporate labor consumption. As part of the system, and, in most cases, a consumer of a part of the farm production, metabolized food energy would correspond to an internal flow when the embodied energy related to its lifestyle would be external. Human lifestyle, as well as auxiliary service consumption, is generally appreciated with an input-output economic analysis, and could correspond to Murphy's levels 4 and 5.

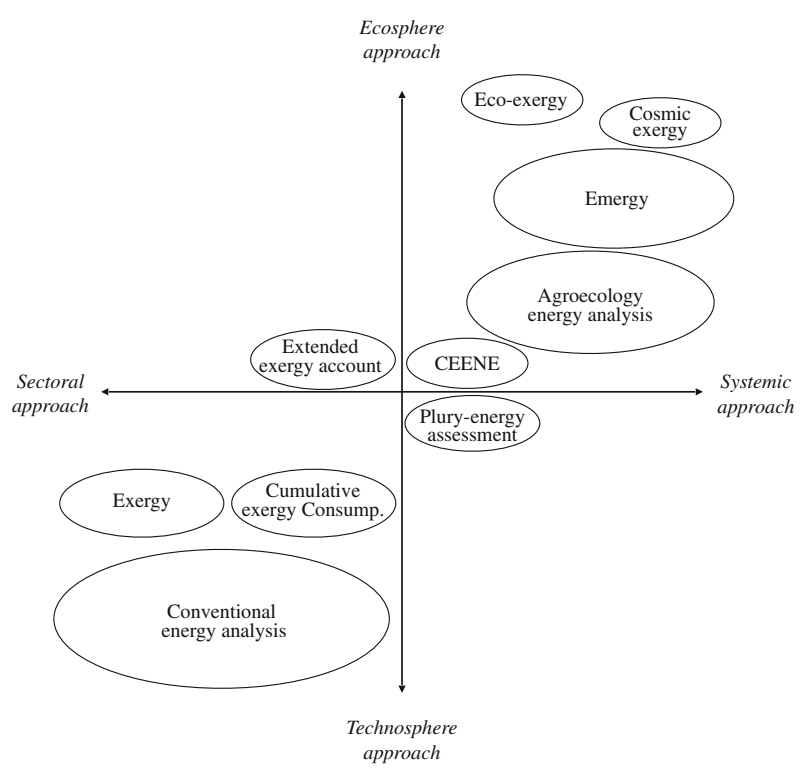

a) Technosphere/Ecosphere approach versus Sectoral/Systemic approach.

\subsection{Consideration of internal flows}

The internal flow of the system has, indeed, recently received increased attention in energy analysis, as the maintenance of the agroecosystem function is crucial (Tello et al. 2015). A recent article suggests that improvement in the efficiency in motors and in the use of fertilizers (i.e., the main drivers in energy efficiency) has already reached or is close to a plateau (Harchaoui and Chatzimpiros 2018). The increase in energy efficiency due to technological progress for the last decades appears small (Hamilton et al. 2013). This implies that any improvement in energy efficiency of the farm system and the capacity to reduce external inputs (and trying to maintain actual output level) ought to essentially depend on operative management decisions (i.e., reduction in time use machine, economy of scale). Another solution for increasing efficiency could involve the increased use of the biomass on-farm by managing the internal circulation of flows, which is a key feature in the prospect of agroecology intensification. Ecological network analysis (Rufino et al. 2009) and indicators such as the system through flow and its relation with system resilience are noteworthy lines of research in this direction. Another useful model has recently appeared to address this problem: the Sustainable Agroecological Farm Reproductive Analysis (SAFRA). It is a linear programming model optimizing land, livestock, and labor used according to different aims (i.e., land-saving, labor-saving, commercial maximization) under a set of biophysical site-specific

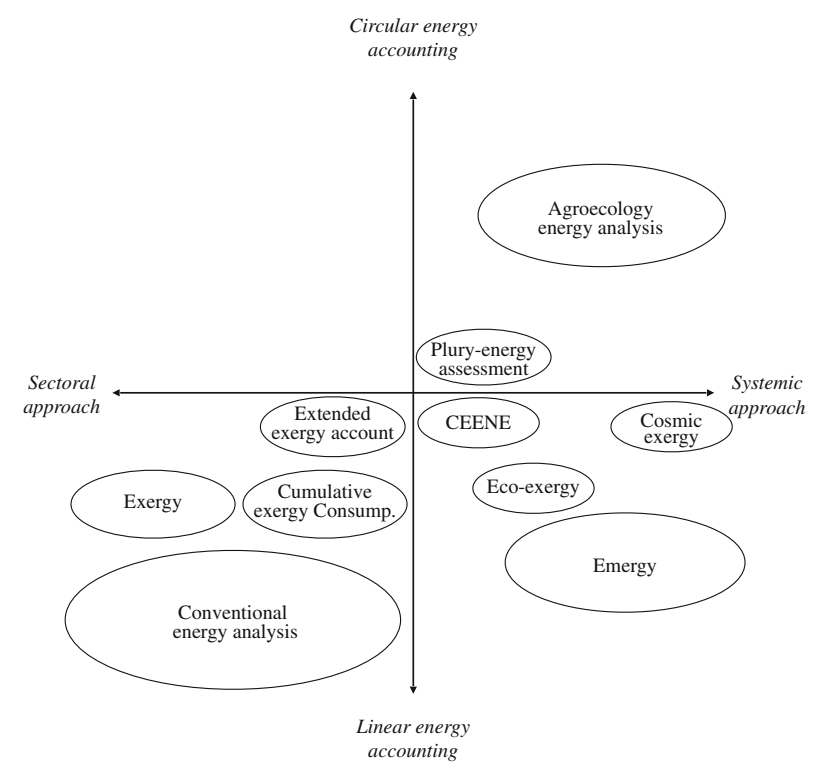

b) Linear/Circular energy accounting versus Sectoral/Systemic approach.

Fig. 7 Classifying energetic approaches through their granularity (sectoral/systemic approach), spheres of concern (technosphere enlarged to ecosphere), and circularity (linear/circular). The pattern size represents the numbers of publications 
constraints (Padró et al. 2019). Tools for managing on-farm flows, and building scenarios of different configuration and scale of intensification are a promising field of investigation.

\subsection{Ability of the approaches to address sustainability issues}

Understanding sustainability mobilizes concepts such as agroecology, bioeconomy, circularity, and systemic approaches. Figure $7 \mathrm{a}$ and $\mathrm{b}$ defines the approaches according to their system granularity (sectorial/systemic approaches), spheres of concern (technosphere enlarged to ecosphere (Fig. 7a) and circularity (Fig. 7b). Conventional energy assessment looks at energy carrier consumption, and evaluates system energy efficiency for economic purpose as energy carriers have a strong impact on economic sustainability of the farm system. Through its generic model, pluri-energy assessment is a first interesting attempt to open the black box of farm system suggesting the circulation of internal flows. Exergy and CExC share this sectoral/linear and sectoral/technosphere approach (Fig. 7a). Extended Exergy Assessment differs. It introduces the ecosphere by evaluating ecological sustainability in terms of "exergy of environmental remediation cost". At the difference of the other exergy-based analysis, CEENE quantifies the total exergy that is contained in the various resources that are retrieved from the natural environment. Its aim is the impact assessment of resource consumption and it offers a more systemic approach. Eco-exergy would be in contrast with technological exergy, the ecological exergy measurement. Eco-exergy suggests that the accumulated biomass in a system is the exergy content far away from its thermodynamic equilibrium (called by Jorgensen as "inorganic sup") and related to the development, the complexity, and the biodiversity of an agroecosystem. On the latter, Jorgensen states that eco-exergy is not enough to evaluate ecosystem sustainability, and it is necessary to include biodiversity as an indicator (Dalgaard 1995) (e.g., Shannon's index).

Nonetheless, agroecological energy analysis (AEA) and emergy offer a wider systemic approach, considering agriculture as part of a larger system. AEA addresses agroecosystem profile and patterns, looking at territorial socio-metabolic exchanges. Emergy evaluates the agriculture as part of a global solar ecosystem, looking its global resource use, environmental impact, and overall sustainability. Yet, AEA and emergy mobilize two different meanings in their accounting of resource use. Emergy is linear, based on ecological rules (e.g., self-organized and hierarchical), considering energy as a succession of transformation from large flow of low quality to smaller volume of higher quality. AEA addresses a circular approach to evaluate farm system suitability by looking at the loop in the system as the biomass reinvested in the agroecosystem in order to maintain its functionality (Fig. 7b). In AEA, circularity is mobilized exclusively to evaluate biomass flow inside the agroecosystem, excluding the analysis of external inputs circularity (e.g., industrial ecology). Enlarging circularity on the other external inputs for AEA would reinforce assessment of the farm system integration in its territory, calling for multi-scale analysis and is a current line of research in addressing sustainability issues.

\section{Conclusion}

Energy flows are useful in the modeling of agricultural production systems as human activity is strongly related to the use of energy, and particularly since the Industrial Revolution, of fossil energy. Energy is also a key factor for explaining ecosystem process. We identified ten energetic assessments of agricultural production systems that are performed to account energetic flows: (i) conventional energy analysis, (ii) pluri-energy analysis, (iii) agroecological energy analysis, (iv) exergy analysis, (v) cumulative exergy consumption, (vi) extended exergy account, (vii) Cumulative Exergy Extraction from the Natural Environment (CEENE), (viii) eco-exergy, (ix) cosmic exergy analysis, and (x) emergy assessment. CEENE, cosmic exergy analysis, and emergy allow for a better evaluation of natural resources offering the widest boundary system, considering primary natural resources used. The main advantage of emergy and exergy is also their ability to distinguish energy types in terms of quality and to consider lost in energetic processes. However, energy analysis, in terms of heating value, has the advantage of being close to presentday economic indicators and of allowing a better understanding by the operators of the agricultural production system. This review focuses on energy analysis as it was the principal energetic assessment of the corpus. Comparison and benchmarking are difficult to carry out due to variability in the system boundary and in energetic value. However, energy assessment allows a good description of the resources consumed by the farm system.

The tendency of energy assessment to focus on socioeconomic flows without considering ecosystem mechanisms becomes an issue in the case of human activities depending on the agroecosystem. Thus, recent studies have overcome these difficulties by introducing a circular perspective to energy assessment (Guzmán et al. 2015; Tello et al. 2016). Internal flows and biomass reuse management appear as key components in the functionality and sustainability of agricultural production systems. By considering the farm energy production in terms of Net Primary Production, these internal flows are better assessed and introduce a new scale of analysis of the on-farm energy flows. Soil organic matter has proved to be a significant component in the agroecosystem energetic balance, acting as a battery of the agroecosystem, the storage being a key element in energy. Effects on biotic energy storage (e.g., SOM in soil, biomass in a perennial plant), on the 
stability and resilience of an agroecosystem, are noteworthy questions for future studies. In addition, the energy time path, and the simultaneity between the energy output and energy requirement of the system component are issues that have not yet received sufficient attention in energy assessment.

At the end, this review reveals that each of the identified approaches has advantages and limitations for assessing resource efficiency of on-farm agricultural systems. Some of these energy-exergy-emergy approaches are more comprehensive, more capable of being applied at different scales simultaneously, or more capable to account for different energetic flows and resource consumption. To get a multidimensional understanding of agricultural systems, it would be worthwhile to combine them but that implies dilemmas and trade-offs. Those questions deserve a study in itself to identify more deeply complementarities between the energetic approaches.

Acknowledgments The authors wish to thank the reviewers for their proffering suggestions that contribute in improving the manuscript.

Authors' contribution Conceptualization: JHP, CS, EL, and AH; methodology: JHP, AH, and EL; investigation: JHP and AH; writingoriginal draft: JHP; writing - review and editing: AH and EL; supervision: $\mathrm{AH}$ and $\mathrm{CS}$.

\section{Compliance with ethical standards}

Conflict of interest The authors declare that they have no conflict of interest.

\section{References}

Abaidoo S, Dickinson H (2009) Alternative and conventional agricultural paradigms: evidence from farming in Southwest Saskatchewan*. Rural Sociol 67:114-131. https://doi.org/10.1111/j.1549-0831. 2002.tb00096.x

Agostinho F, Diniz G, Siche R, Ortega E (2008) The use of emergy assessment and the Geographical Information System in the diagnosis of small family farms in Brazil. Ecol Model 210:37-57. https:// doi.org/10.1016/j.ecolmodel.2007.07.007

Aguilera E, Guzmán Casado G, Infante Amate J, et al (2015) Embodied energy in agricultural inputs. Incorporating a historical perspective. Sociedad Española de Historia Agraria

Ahamed JUU, Saidur R, Masjuki HHH et al (2011) An application of energy and exergy analysis in agricultural sector of Malaysia. Energy Policy 39:7922-7929. https://doi.org/10.1016/j.enpol. 2011.09.045

Alhameid A, Tobin C, Maiga A, et al (2017) Intensified agroecosystems and changes in soil carbon dynamics. In: Soil health and intensification of agroecosytems. Elsevier, pp 195-214

Alluvione F, Moretti B, Sacco D, Grignani C (2011) EUE (energy use efficiency) of cropping systems for a sustainable agriculture. Energy 36:4468-4481. https://doi.org/10.1016/j.energy.2011.03.075

Alonso AM, Guzmán GJ (2010) Comparison of the efficiency and use of energy in organic and conventional farming in Spanish agricultural systems. J Sustain Agric 34:312-338. https://doi.org/10.1080/ 10440041003613362
Amaral LP, Martins N, Gouveia JB (2016) A review of emergy theory, its application and latest developments. Renew Sust Energ Rev 54: 882-888. https://doi.org/10.1016/j.rser.2015.10.048

Amiri Z, Asgharipour MR, Campbell DE, Armin M (2020) Extended exergy analysis (EAA) of two canola farming systems in Khorramabad, Iran. Agric Syst 180:102789. https://doi.org/10. 1016/j.agsy.2020.102789

An S, Bao H, Zou C (1998) Studies of emergy flow in a compound agroecosystem in the Taihu Lake area, Jiangsu Province, China. Ecol Eng 11:303-313. https://doi.org/10.1016/S0925-8574(98)00040-8

Arodudu O, Helming K, Wiggering H, Voinov A (2016) Bioenergy from low-intensity agricultural systems: an energy efficiency analysis. Energies 10:29. https://doi.org/10.3390/en10010029

Arodudu OT, Helming K, Voinov A, Wiggering H (2017) Integrating agronomic factors into energy efficiency assessment of agrobioenergy production - a case study of ethanol and biogas production from maize feedstock. Appl Energy 198:426-439. https://doi. org/10.1016/j.apenergy.2017.02.017

Arrieta EMM, Cuchietti A, Cabrol D, González ADD (2018) Greenhouse gas emissions and energy efficiencies for soybeans and maize cultivated in different agronomic zones: a case study of Argentina. Sci Total Environ 625:199-208. https://doi.org/10.1016/j.scitotenv. 2017.12.286

Atlason RS, Kjaerheim KM, Davidsdottir B, Ragnarsdottir KV (2015) A comparative analysis of the energy return on investment of organic and conventional Icelandic dairy farms. ICELANDIC Agric Sci 28: 29-42. https://doi.org/10.16886/IAS.2015.04

Bailey AP, Basford WD, Penlington N et al (2003) A comparison of energy use in conventional and integrated arable farming systems in the UK. Agric Ecosyst Environ 97:241-253. https://doi.org/10. 1016/S0167-8809(03)00115-4

Balogh S.B., Hall C.A.S, Guzman A.M., Balcarce D.E., A. H (2012) The potential of Onondaga County to feed the population of Syracuse, New York: past, present and future. In: Pimentel D (ed) Global economic and environmental aspects of biofuel. CRC Press, Boca Raton

Barak S, Yousefi M, Maghsoudlou H, Jahangiri S (2016) Energy and GHG emissions management of agricultural systems using multi objective particle swarm optimization algorithm: a case study. Stoch Environ Res Risk Assess 30:1167-1187. https://doi.org/10. 1007/s00477-015-1098-1

Bartzas G, Komnitsas K (2018) Energy flow analysis in agriculture; the case of irrigated pistachio production in Greece. Sustain Energy Technol Assessments 28:73-80. https://doi.org/10.1016/j.seta. 2018.06.007

Baum AW, Patzek T, Bender M et al (2009) The visible, sustainable farm: a comprehensive energy analysis of a Midwestern farm. CRC Crit Rev Plant Sci 28:218-239. https://doi.org/10.1080/ 07352680902963915

Beheshti Tabar I, Keyhani A, Rafiee S (2010) Energy balance in Iran's agronomy (1990-2006). Renew Sust Energ Rev 14:849-855. https://doi.org/10.1016/j.rser.2009.10.024

Benoit M, Laignel G (2010) Energy consumption in mixed crop-sheep farming systems: what factors of variation and how to decrease? Animal 4:1597-1605. https://doi.org/10.1017/ S1751731110000480

Bhatt BP, Bujarbaruah KM (2011) Eco-energetic analysis of integrated agro-aquaculture models, north eastern Himalayan region, India. J Sustain Agric 35:493-510. https://doi.org/10.1080/10440046.2011. 579835

Blancard S, Martin E (2014) Energy efficiency measurement in agriculture with imprecise energy content information. Energy Policy 66: 198-208. https://doi.org/10.1016/j.enpol.2013.10.071

Bochu J (2006) Consommation et efficacité énergétique de différents systèmes de production agricoles avec la méthodologie $\mathrm{P}$ LANETE. Fourrages 186:165-177 
Bonny S (2011) L'agriculture écologiquement intensive Nature et défis. Cah Agric 20:451-462. https://doi.org/10.1684/agr.2011.0526

Bos JFFP, de Haan J, Sukkel W et al (2014) Energy use and greenhouse gas emissions in organic and conventional farming systems in the Netherlands. NJAS - Wageningen J Life Sci 68:61-70. https://doi. org/10.1016/j.njas.2013.12.003

Boulanger P (2004) Les indicateurs de développement durable : un défi scientifique, un enjeu démocratique Séminaire Développement durable et économie de 1 ' environnement. Les Semin l'Iddri n 12 1-24

Brown MT, Ulgiati S (2004) Emergy analysis and environmental accounting. Encycl Energy 2:329-354. https://doi.org/10.1016/B012-176480-X/00242-4

Budzyński WS, Jankowski KJJ, Jarocki M et al (2015) An analysis of the energy efficiency of winter rapeseed biomass under different farming technologies. A case study of a large-scale farm in Poland. Energy 90:1272-1279. https://doi.org/10.1016/j.energy.2015.06. 087

Bulatkin GA (2012) Analysis of energy flows in agroecosystems. Her Russ Acad Sci 82:326-334. https://doi.org/10.1134/ S1019331612040089

Camargo GGT, Ryan MR, Richard TL (2013) Energy use and greenhouse gas emissions from crop production using the farm energy analysis tool. Bioscience 63:263-273. https://doi.org/10.1525/bio. 2013.63.4.6

Cattaneo C, Marull J, Tello E (2018) Landscape Agroecology. The dysfunctionalities of industrial agriculture and the loss of the circular bioeconomy in the Barcelona Region, 1956-2009. Sustain 10:. https://doi.org/10.3390/su10124722

Cavalett O, de Queiroz JF, Ortega E (2006) Emergy assessment of integrated production systems of grains, pig and fish in small farms in the South Brazil. Ecol Model 193:205-224. https://doi.org/10.1016/ j.ecolmodel.2005.07.023

Chen G, Baillie C (2009) Development of a framework and tool to asses on-farm energy uses of cotton production. Energy Convers Manag 50:1256-1263. https://doi.org/10.1016/j.enconman.2009.01.022

Chen GQ (2006) Scarcity of exergy and ecological evaluation based on embodied exergy. Commun Nonlinear Sci Numer Simul 11:531552. https://doi.org/10.1016/j.cnsns.2004.11.009

Chen GQ, Jiang MM, Chen B et al (2006) Emergy analysis of Chinese agriculture. Agric Ecosyst Environ 115:161-173. https://doi.org/10. 1016/j.agee.2006.01.005

Chen GQ, Jiang MM, Yang ZF et al (2009) Exergetic assessment for ecological economic system: Chinese agriculture. Ecol Model 220: 397-410. https://doi.org/10.1016/j.ecolmodel.2008.10.006

Chen ZM, Chen B, Chen GQ (2011) Cosmic exergy based ecological assessment for a wetland in Beijing. Ecol Model 222:322-329. https://doi.org/10.1016/j.ecolmodel.2010.09.023

Choudhary M, Rana KS, Bana RS et al (2017) Energy budgeting and carbon footprint of pearl millet - mustard cropping system under conventional and conservation agriculture in rainfed semi-arid agroecosystem. Energy 141:1052-1058. https://doi.org/10.1016/j. energy.2017.09.136

Clark S, Khoshnevisan B, Sefeedpari P (2016) Energy efficiency and greenhouse gas emissions during transition to organic and reduced-input practices: student farm case study. Ecol Eng 88: 186-194. https://doi.org/10.1016/j.ecoleng.2015.12.036

Cleveland CJ (1995) Resource degradation, technical change, and the productivity of energy use in U.S. agriculture. Ecol Econ 13:185201. https://doi.org/10.1016/0921-8009(95)00005-T

Cunfer G, Watson A, MacFadyen J (2018) Energy profiles of an agricultural frontier: the American Great Plains, 1860-2000. Reg Environ Chang 18:1021-1032. https://doi.org/10.1007/s10113-017-1157-x

Dalgaard JPT (1995) Applying systems ecology to the analysis of integrated agriculture-aquaculture farms. NAGA, INCLARM Q

Dalgaard T, Halberg N, Porter JR (2001) A model for fossil energy use in Danish agriculture used to compare organic and conventional farming. Agric Ecosyst Environ 87:51-65. https://doi.org/10.1016/ S0167-8809(00)00297-8

Daviron (2016) Agriculture et économie : du solaire au minier... et retour ? Agron Environ sociétés n ${ }^{\circ} 6$ :

Dewulf J, Boesch ME, De Meester B et al (2007) Cumulative exergy extraction from the natural environment (CEENE): a comprehensive life cycle impact assessment method for resource accounting. Environ Sci Technol 41:8477-8483. https://doi.org/10.1021/ es0711415

Dewulf J, Van Langenhove H, Muys B et al (2008) Exergy: its potential and limitations in environmental science and technology. Environ Sci Technol 42:2221-2232. https://doi.org/10.1021/es071719a

Diacono M, Persiani A, Fiore A et al (2017) Agro-ecology for potential adaptation of horticultural systems to climate change: agronomic and energetic performance evaluation. Agronomy 7:35. https://doi. org/10.3390/agronomy 7020035

Diemont SAW, Martin JF, Levy-Tacher SI (2006) Emergy evaluation of Lacandon Maya indigenous Swidden agroforestry in Chiapas, Mexico. Agrofor Syst 66:23-42. https://doi.org/10.1007/s10457005-6073-2

Díez L, Cussó X, Padró R, et al (2018) More than energy transformations: a historical transition from organic to industrialized farm systems in a Mediterranean village (Les Oluges, Catalonia, 1860-1959-1999). Int J Agric Sustain 0:1-19. https://doi.org/10.1080/14735903.2018. 1520382

Dincer I, Hussain MMM, Al-Zaharnah I (2005) Energy and exergy utilization in agricultural sector of Saudi Arabia. Energy Policy 33: 1461-1467. https://doi.org/10.1016/j.enpol.2004.01.004

Elsoragaby S, Yahya A, Mahadi MR et al (2019) Energy utilization in major crop cultivation. Energy 173:1285-1303. https://doi.org/10. 1016/j.energy.2019.01.142

Fan J, McConkey BG, Janzen HH, Miller PR (2018) Emergy and energy analysis as an integrative indicator of sustainability: a case study in semi-arid Canadian farmlands. J Clean Prod 172:428-437. https:// doi.org/10.1016/j.jclepro.2017.10.200

Fathollahi H, Mousavi-Avval SH, Akram A, Rafiee S (2018) Comparative energy, economic and environmental analyses of forage production systems for dairy farming. J Clean Prod 182:852862. https://doi.org/10.1016/j.jclepro.2018.02.073

Felten D, Fröba N, Fries J, Emmerling C (2013) Energy balances and greenhouse gas-mitigation potentials of bioenergy cropping systems (Miscanthus, rapeseed, and maize) based on farming conditions in Western Germany. Renew Energy 55:160-174. https://doi.org/10. 1016/j.renene.2012.12.004

Firrisa MT, van Duren I, Voinov A (2014) Energy efficiency for rapeseed biodiesel production in different farming systems. Energy Effic 7: 79-95. https://doi.org/10.1007/s12053-013-9201-2

Fluck RC (1992) Energy of human labor. In: Energy in farm production. Elsevier, pp 31-37

Fluck RC (1981) Net energy sequestered in agricultural labor. Trans ASAE 24:1449-1455. https://doi.org/10.13031/2013.34471

Fore SR, Porter P, Lazarus W (2011) Net energy balance of small-scale on-farm biodiesel production from canola and soybean. Biomass Bioenergy 35:2234-2244. https://doi.org/10.1016/j.biombioe. 2011.02.037

Fraňková E, Cattaneo C (2018) Organic farming in the past and today: sociometabolic perspective on a Central European case study. Reg Environ Chang 18:951-963. https://doi.org/10.1007/s10113-0161099-8

Fredriksson H, Baky A, Bernesson S et al (2006) Use of on-farm produced biofuels on organic farms - evaluation of energy balances and environmental loads for three possible fuels. Agric Syst 89:184 203. https://doi.org/10.1016/j.agsy.2005.08.009

Galán E, Padró R, Marco I et al (2016) Widening the analysis of energy return on investment (EROI) in agro-ecosystems: socio-ecological transitions to industrialized farm systems (the Vallès County, 
Catalonia, c.1860 and 1999). Ecol Model 336:13-25. https://doi. org/10.1016/j.ecolmodel.2016.05.012

Georgescu-Roegen N (1971) The entropy law and the economic process /Nicholas Georgescu-Roegen. Harvard University Press, Cambri

Ghandoor AA, Jaber JO (2009) Analysis of energy and exergy utilisation of Jordan's agricultural sector. Int J Exergy 6:491. https://doi.org/10. 1504/IJEX.2009.026674

Ghisellini P, Setti M, Ulgiati S (2016) Energy and land use in worldwide agriculture: an application of life cycle energy and cluster analysis. Environ Dev Sustain 18:799-837. https://doi.org/10.1007/s10668015-9678-2

Ghorbani R, Mondani F, Amirmoradi S et al (2011) A case study of energy use and economical analysis of irrigated and dryland wheat production systems. Appl Energy 88:283-288. https://doi.org/10. 1016/j.apenergy.2010.04.028

Giampietro M, Cerretelli G, Pimentel D (1992) Energy analysis of agricultural ecosystem management: human return and sustainability. Agric Ecosyst Environ 38:219-244. https://doi.org/10.1016/01678809(92)90146-3

Giampietro M, Pimentel D (1990) Assessment of the energetics of human labor. Agric Ecosyst Environ 32:257-272. https://doi.org/10.1016/ 0167-8809(90)90164-9

Giannetti BF, Ogura Y, Bonilla SH, Almeida CMVB (2011) Emergy assessment of a coffee farm in Brazilian Cerrado considering in a broad form the environmental services, negative externalities and fair price. Agric Syst 104:679-688. https://doi.org/10.1016/j.agsy. 2011.08.001

Gingrich S, Cunfer G, Aguilera E (2018a) Agroecosystem energy transitions: exploring the energy-land nexus in the course of industrialization. Reg Environ Chang 18:929-936. https://doi.org/10.1007/ s10113-018-1322-x

Gingrich S, Krausmann F (2018) At the core of the socio-ecological transition: agroecosystem energy fluxes in Austria 1830-2010. Sci Total Environ 645:119-129. https://doi.org/10.1016/j.scitotenv. 2018.07.074

Gingrich S, Marco I, Aguilera E et al (2018b) Agroecosystem energy transitions in the old and new worlds: trajectories and determinants at the regional scale. Reg Environ Chang 18:1089-1101. https://doi. org/10.1007/s10113-017-1261-y

Gingrich S, Theurl MC, Erb K, Krausmann F (2018c) Regional specialization and market integration: agroecosystem energy transitions in Upper Austria. Reg Environ Chang 18:937-950. https://doi.org/10. 1007/s10113-017-1145-1

Gliessman SR (2006) The energetics of agroecosystems. In: Agroecology: ecological processes in sustainable agriculture, CRC press. Boca Raton

Gomiero T (2017) Biophysical analysis of Agri-food systems: scales, energy efficiency, power and metabolism of society. In: Fralvnková E, Haas W, Singh SJ (eds)Socio-metabolic perspectives on the sustainability of local food systems: insights for science, policy and practice,Springer International Publishing, Cham, pp 69-101

Gündoğmuș E, Gu E (2006) Energy use on organic farming: a comparative analysis on organic versus conventional apricot production on small holdings in Turkey. Energy Convers Manag 47:3351-3359. https://doi.org/10.1016/j.enconman.2006.01.001

Gupta AK, Hall CAS (2011) A review of the past and current state of EROI data. Sustainability 3:1796-1809. https://doi.org/10.3390/ su3101796

Guzmán Casado GI, González de Molina M (2017) Energy in Agroecosystems. A tool for assessing sustainability, CRC Press. Boca Raton

Guzmán G, Aguilera E, Soto D, et al (2014) Methodology and conversion factors to estimate the net primary productivity of historical and contemporary agroecosystems. Doc Trab la Soc Española Hist Agrar
Guzmán GI, González de Molina M, de Molina MG et al (2015) Energy efficiency in agrarian systems from an agroecological perspective. Agroecol Sustain Food Syst 39:924-952. https://doi.org/10.1080/ 21683565.2015.1053587

Guzmán GI, González de Molina M, Soto Fernández D et al (2018) Spanish agriculture from 1900 to 2008: a long-term perspective on agroecosystem energy from an agroecological approach. Reg Environ Chang 18:995-1008. https://doi.org/10.1007/s10113-017$1136-2$

Hall CAS (2017) Energy return on investment. Springer International Publishing, Cham, Economics

Hall CAS, Balogh S, Murphy DJR (2009) What is the minimum EROI that a sustainable society must have? Energies 2:25-47. https://doi. org/10.3390/en20100025

Hall CAS, Dale BE, Pimentel D (2011) Seeking to understand the reasons for different energy return on investment (EROI) estimates for biofuels. Sustainability 3:2413-2432. https://doi.org/10.3390/ su3122413

Hamilton A, Balogh S, Maxwell A, Hall CAS (2013) Efficiency of edible agriculture in Canada and the U.S. over the past three and four decades. Energies 6:1764-1793. https://doi.org/10.3390/en6031764

Han C ru, Golley F, Mou, Z gou (1985) Energy analysis of advanced collective farms in North China. Agric Ecosyst Environ 13:217240. https://doi.org/10.1016/0167-8809(85)90013-1

Han L, Jin J, Wu L, Zeng H (2019) The volatility linkage between energy and agricultural futures markets with external shocks. Int Rev Financ Anal:1-15. https://doi.org/10.1016/j.irfa.2019.01.011

Harchaoui S, Chatzimpiros P (2019) Energy, nitrogen, and farm surplus transitions in agriculture from historical data modeling. France, 1882-2013. J Ind Ecol 23:412-425. https://doi.org/10.1111/jiec. 12760

Harchaoui S, Chatzimpiros P (2018) Can agriculture balance its energy consumption and continue to produce food? A framework for assessing energy neutrality applied to French agriculture. Sustainability 10:4624. https://doi.org/10.3390/su10124624

Hoang V-N, Alauddin M (2011) Analysis of agricultural sustainability: a review of exergy methodologies and their application in OECD countries. Int J Energy Res 35:459-476. https://doi.org/10.1002/er. 1713

Hoang V-N, Rao DSP (2010) Measuring and decomposing sustainable efficiency in agricultural production: a cumulative exergy balance approach. Ecol Econ 69:1765-1776. https://doi.org/10.1016/j. ecolecon.2010.04.014

$\mathrm{Hu}$ QH, Zhang LX, Wang CB (2012) Emergy-based analysis of two chicken farming systems: a perception of organic production model in China. Procedia Environ Sci 13:445-454. https://doi.org/10. 1016/j.proenv.2012.01.038

Hülsbergen KJ, Feil B, Biermann S, et al (2001) A method of energy balancing in crop production and its application in a long-term fertilizer trial. Agric Ecosyst Environ 86:303-321. https://doi.org/10. 1016/S0167-8809(00)00286-3

Huysveld S, Van linden V, De Meester S, et al (2015) Resource use assessment of an agricultural system from a life cycle perspective a dairy farm as case study. Agric Syst 135:77-89. https://doi.org/10. 1016/j.agsy.2014.12.008

IAASTD (2009) Synthesis report international assessment of agricultural knowledge, Science and Technology for Development Agriculture Crossroads Agriculture Crossroads at a at a Crossroads Crossroads Crossroads

IFIAS (1974) Energy analysis workshop on methodology and conventions. Int Fed Institutes Adv Study

IFIAS (1978) IFIAS workshop report, energy analysis and economics. Resour Energy 1:151-204. https://doi.org/10.1016/0165-0572(78) 90004-X

Infante-Amate J, Picado W (2018) Energy flows in the coffee plantations of Costa Rica: from traditional to modern systems (1935-2010). 
Reg Environ Chang 18:1059-1071. https://doi.org/10.1007/s10113017-1263-9

Jafari M, Asgharipour MR, Ramroudi M et al (2018) Sustainability assessment of date and pistachio agricultural systems using energy, emergy and economic approaches. J Clean Prod 193:642-651. https://doi.org/10.1016/j.jclepro.2018.05.089

Jaklič T, Juvančič L, Kavčič S, Debeljak M (2014) Complementarity of socio-economic and emergy evaluation of agricultural production systems: the case of Slovenian dairy sector. Ecol Econ 107:469481. https://doi.org/10.1016/j.ecolecon.2014.09.024

Jankowski KJ, Dubis B, Budzyński WS et al (2016) Energy efficiency of crops grown for biogas production in a large-scale farm in Poland. Energy 109:277-286. https://doi.org/10.1016/j.energy.2016.04.087

Jekayinfa SO, Adebayo AO, Afolayan SO, Daramola E (2013) On-farm energetics of mango production in Nigeria. Renew Energy 51:60 63. https://doi.org/10.1016/j.renene.2012.09.004

Jekayinfa SOO, Ola FAA, Afolayan SOO, Ogunwale ROO (2012) Onfarm energy analysis of plantain production in Nigeria. Energy Sustain Dev 16:339-343. https://doi.org/10.1016/j.esd.2012.05.004

Jianbo L (2006) Energy balance and economic benefits of two agroforestry systems in northern and southern China. Agric Ecosyst Environ 116:255-262

Jolliet O, Saadé-Sbeih M, Shaked S et al (2015) Environmental life cycle assessment. CRC Press

Jones MRR (1989) Analysis of the use of energy in agricultureapproaches and problems. Agric Syst 29:339-355. https://doi.org/ 10.1016/0308-521X(89)90096-6

Jordan CF (2016) The farm as a thermodynamic system: implications of the maximum power principle. Biophys Econ Resour Qual 1:1-14. https://doi.org/10.1007/s41247-016-0010-Z

Kocjančič T, Debeljak M, Žgajnar J, Juvančič L (2018) Incorporation of emergy into multiple-criteria decision analysis for sustainable and resilient structure of dairy farms in Slovenia. Agric Syst 164:71-83. https://doi.org/10.1016/j.agsy.2018.03.005

Koesling M, Hansen S, Schueler M (2017) Variations of energy intensities and potential for improvements in energy utilisation on conventional and organic Norwegian dairy farms. J Clean Prod 164:301314. https://doi.org/10.1016/j.jclepro.2017.06.124

Kraatz S (2012) Energy intensity in livestock operations - modeling of dairy farming systems in Germany. Agric Syst 110:90-106. https:// doi.org/10.1016/j.agsy.2012.03.007

Krausmann F (2016) From energy source to sink: transformations of Austrian agriculture. In: Haberl H, FischerKowalski M, Krausmann F, Winiwarter V (eds) Social ecology. Springer International Publishing, Cham, pp 433-445

Krausmann F (2008) Land use and socioeconomic metabolism in preindustrial agricultural systems : four nineteenth-century Austrian villages in comparison land use and socio-economic metabolism in pre-industrial agricultural systems : four nineteenth-century Austrian villages. Alpen-adria-universit Social Eco

Kuczuk A, Pospolita J, Wacław S (2017) Energy and emergy analysis of mixed crop-livestock farming. E3S web Conf 19:02033. https://doi. org/10.1051/e3sconf/20171902033

Kuesters J, Lammel J (1999) Investigations of the energy efficiency of the production of winter wheat and sugar beet in Europe. Eur J Agron 11:35-43. https://doi.org/10.1016/S1161-0301(99)00015-5

La Rosa ADD, Siracusa G, Cavallaro R (2008) Emergy evaluation of Sicilian red orange production. A comparison between organic and conventional farming J Clean Prod 16:1907-1914. https://doi.org/ 10.1016/j.jclepro.2008.01.003

Lin H-C, Huber JA, Gerl G, Hülsbergen K-J (2017) Effects of changing farm management and farm structure on energy balance and energyuse efficiency - a case study of organic and conventional farming systems in southern Germany. Eur J Agron 82:242-253. https://doi. org/10.1016/j.eja.2016.06.003
Liu Z, Wang D-Y, Li G et al (2017) Cosmic exergy-based ecological assessment for farmland-dairy-biogas agroecosystems in North China. J Clean Prod 159:317-325. https://doi.org/10.1016/j. jclepro.2017.05.056

Loiseau E, Junqua G, Roux P, Bellon-Maurel V (2012) Environmental assessment of a territory: an overview of existing tools and methods. J Environ Manag 112:213-225. https://doi.org/10.1016/j.jenvman. 2012.07.024

Lu H, Bai Y, Ren H, Campbell DE (2010) Integrated emergy, energy and economic evaluation of rice and vegetable production systems in alluvial paddy fields: implications for agricultural policy in China. J Environ Manag 91:2727-2735. https://doi.org/10.1016/j.jenvman. 2010.07.025

MacFadyen J, Watson A (2018) Energy in a woodland-livestock agroecosystem: Prince Edward Island, Canada, 1870-2010. Reg Environ Chang 18:1033-1045. https://doi.org/10.1007/s10113018-1315-9

Manso R, Sousa T, Domingos T (2017) Do the different exergy accounting methodologies provide consistent or contradictory results? A case study with the Portuguese agricultural, forestry and fisheries sector. Energies 10:1219. https://doi.org/10.3390/en10081219

Maraseni T, Chen G, Banhazi T et al (2015) An assessment of direct onfarm energy use for high value grain crops grown under different farming practices in Australia. Energies 8:13033-13046. https://doi. org/10.3390/en 81112353

Marco I, Padró R, Cattaneo C, Caravaca J, Tello E (2018) From vineyards to feedlots: a fund-flow scanning of sociometabolic transition in the Vallès County (Catalonia) 1860-1956-1999. Reg Environ Chang 18:981-993. https://doi.org/10.1007/s10113-017-1172-y

Martin JF, Diemont SAW, Powell E et al (2006) Emergy evaluation of the performance and sustainability of three agricultural systems with different scales and management. Agric Ecosyst Environ 115:128140. https://doi.org/10.1016/j.agee.2005.12.016

Marull J, Font C, Padró R et al (2016) Energy-landscape integrated analysis: a proposal for measuring complexity in internal agroecosystem processes (Barcelona metropolitan region, 1860 2000). Ecol Indic 66:30-46. https://doi.org/10.1016/j.ecolind.2016. 01.015

Mendoza TC (2005) An energy-based analysis of organic, low external input sustainable agriculture (LEISA) and conventional rice production in the Philippines. Philipp Agric Sci 88:257-267

Migliorini P, Chiorri M, Paffarini C, Galioto F (2012) Energy analysis of organic horticultural farms in Italy. NEW MEDIT 11:49-52

Mohammadi A, Rafiee S, Jafari A et al (2014) Energy use efficiency and greenhouse gas emissions of farming systems in north Iran. Renew Sust Energ Rev 30:724-733. https://doi.org/10.1016/j.rser.2013.11. 012

Mohr SH, Wang J, Ellem G et al (2015) Projection of world fossil fuels by country. Fuel 141:120-135. https://doi.org/10.1016/j.fuel.2014.10. 030

Mrini M, Senhaji F, Pimentel D (2002) Energy analysis of sugar beet production under traditional and intensive farming systems and impacts on sustainable agriculture in Morocco. J Sustain Agric 20:528. https://doi.org/10.1300/J064v20n04_03

de Muner LH, Masera O, Fornazier MJMJMJ et al (2015) Energetic sustainability of three arabica coffee growing systems used by family farming units in Espírito Santo state. Eng Agrícola 35:397-405. https://doi.org/10.1590/1809-4430-Eng.Agric.v35n3p397-405/ 2015

Murphy DJ, Hall CAS, Dale M, Cleveland C (2011) Order from chaos: a preliminary protocol for determining the EROI of fuels. Sustainability 3:1888-1907. https://doi.org/10.3390/su3101888

OCDE/FAO (2017) Perspectives agricoles de l'OCDE et de la FAO 2017-2026, OCDE. Éditions OCDE

Odum HT (1983) Systems ecology; an introduction, USA 
Odum HT (1984) Energy analysis of the environmental role in agriculture. In: Stanhill G (ed) Energy and agriculture. Springer, Berlin, pp 24-51

Odum HT (1973) Energy, ecology, and economics. Ambio 2:220-227

Padró R, Marco I, Cattaneo C, et al (2017) Does your landscape mirror what you eat? A Long-term socio-metabolic analysis of a local food system in Vallès County (Spain, 1860-1956-1999). In: Fralvnková E, Haas W, Singh SJ (eds) Socio-metabolic perspectives on the sustainability of local food systems: insights for science, policy and practice,Springer, Cham, pp 133-164

Padró R, Marco I, Font C, Tello E (2019) Beyond Chayanov: a sustainable agroecological farm reproductive analysis of peasant domestic units and rural communities (Sentmenat; Catalonia, 1860). Ecol Econ 160:227-239. https://doi.org/10.1016/j.ecolecon.2019.02.009

Pagani M, Vittuari M, Johnson TG, De Menna F (2016) An assessment of the energy footprint of dairy farms in Missouri and EmiliaRomagna. Agric Syst 145:116-126. https://doi.org/10.1016/j.agsy. 2016.03.009

Parcerisas L, Dupras J (2018) From mixed farming to intensive agriculture: energy profiles of agriculture in Quebec, Canada, 1871-2011. Reg Environ Chang 18:1047-1057. https://doi.org/10.1007/s10113018-1305-y

Patrizi N, Niccolucci V, Castellini C et al (2018) Sustainability of agrolivestock integration: implications and results of Emergy evaluation. Sci Total Environ 622-623:1543-1552. https://doi.org/10.1016/j. scitotenv.2017.10.029

Patzek TW (2004) Thermodynamics of the corn-ethanol biofuel cycle. CRC Crit Rev Plant Sci 23:519-567. https://doi.org/10.1080/ 07352680490886905

Pelletier N, Audsley E, Brodt S et al (2011) Energy intensity of agriculture and food systems. Annu Rev Environ Resour 36:223-246. https://doi.org/10.1146/annurev-environ-081710-161014

Pérez Neira D (2016) Energy efficiency of cacao agroforestry under traditional and organic management. Agron Sustain Dev 36:49. https:// doi.org/10.1007/s13593-016-0386-6

Pérez Neira D, Montiel MS, Fernández XS (2012) Energy analysis of organic farming in Andalusia (Spain). J Sustain Agric 37: 121008070803004. https://doi.org/10.1080/10440046.2012. 734263

Pérez Neira D, Soler Montiel M, Delgado Cabeza M, Reigada A (2018) Energy use and carbon footprint of the tomato production in heated multi-tunnel greenhouses in Almeria within an exporting agri-food system context. Sci Total Environ 628-629:1627-1636. https://doi. org/10.1016/j.scitotenv.2018.02.127

Pérez Neira D, Soler Montiel M, Fernández XS (2014) Energy indicators for organic livestock production: a case study from Andalusia, southern Spain. Agroecol Sustain Food Syst 38:317-335. https:// doi.org/10.1080/21683565.2013.833154

Perryman ME, Schramski JR (2015) Evaluating the relationship between natural resource management and agriculture using embodied energy and eco-exergy analyses: a comparative study of nine countries. Ecol Complex 22:152-161. https://doi.org/10.1016/j.ecocom.2015. 04.002

Pimentel D (1976) Energy in food production. Am Biol Teach 38:402404. https://doi.org/10.2307/4445650

Pimentel D, Cerasale D, Stanley RC et al (2012) Annual vs. perennial grain production. Agric Ecosyst Environ 161:1-9. https://doi.org/ 10.1016/j.agee.2012.05.025

Pimentel D, Hurd LE, Bellotti AC, et al (1973) Food production and the energy crisis. Science (80- ) 182:443-449

Pimentel D, Patzek TW (2007) Ethanol production using corn, switchgrass, and wood; biodiesel production using soybean and sunflower. Food, Energy, Soc Third Ed 14:311-332. https://doi.org/10.1201/ 9781420046687

Pishgar-Komleh SH, Akram A, Keyhani A, van Zelm R (2017) Life cycle energy use, costs, and greenhouse gas emission of broiler farms in different production systems in Iran - a case study of Alborz province. Environ Sci Pollut Res 24:16041-16049. https://doi.org/10. 1007/s11356-017-9255-3

Pishgar-Komleh SH, Ghahderijani M, Sefeedpari P (2012) Energy consumption and $\mathrm{CO} 2$ emissions analysis of potato production based on different farm size levels in Iran. J Clean Prod 33:183-191. https:// doi.org/10.1016/j.jclepro.2012.04.008

Pishgar-Komleh SH, Sefeedpari P, Rafiee S (2011) Energy and economic analysis of rice production under different farm levels in Guilan province of Iran. Energy 36:5824-5831. https://doi.org/10.1016/j. energy.2011.08.044

Pizzigallo ACI, Granai C, Borsa S (2008) The joint use of LCA and emergy evaluation for the analysis of two Italian wine farms. J Environ Manag 86:396-406. https://doi.org/10.1016/j.jenvman. 2006.04.020

Pragya N, Sharma N, Gowda B (2017) Biofuel from oil-rich tree seeds: net energy ratio, emissions saving and other environmental impacts associated with agroforestry practices in Hassan district of Karnataka, India. J Clean Prod 164:905-917. https://doi.org/10. 1016/j.jclepro.2017.07.005

Pratibha G, Srinivas I, Rao KV et al (2015) Impact of conservation agriculture practices on energy use efficiency and global warming potential in rainfed pigeonpea-castor systems. Eur J Agron 66:30-40. https://doi.org/10.1016/j.eja.2015.02.001

Pryor SW, Smithers J, Lyne P, van Antwerpen R (2017) Impact of agricultural practices on energy use and greenhouse gas emissions for South African sugarcane production. J Clean Prod 141:137-145. https://doi.org/10.1016/j.jclepro.2016.09.069

Rahman MM, Mostafiz SB, Paatero JV, Lahdelma R (2014) Extension of energy crops on surplus agricultural lands: a potentially viable option in developing countries while fossil fuel reserves are diminishing. Renew Sust Energ Rev 29:108-119. https://doi.org/ 10.1016/j.rser.2013.08.092

Rahman S, Barmon BK (2012) Energy productivity and efficiency of the 'gher' (prawn-fish-rice) farming system in Bangladesh. Energy 43: 293-300. https://doi.org/10.1016/j.energy.2012.04.027

Rahman S, Hasan MK (2014) Energy productivity and efficiency of wheat farming in Bangladesh. Energy 66:107-114 https://doi.org/ 10.1016/j.energy.2013.12.070

Ramedani Z, Rafiee S, Heidari MD (2011) An investigation on energy consumption and sensitivity analysis of soybean production farms. Energy 36:6340-6344. https://doi.org/10.1016/j.energy.2011.09. 042

Refsgaard K, Halberg N, Kristensen ES (1998) Energy utilization in crop and dairy production in organic and conventional livestock production systems. Agric Syst 57:599-630. https://doi.org/10.1016/ S0308-521X(98)00004-3

Risoud B (1999) Développement durable et analyse énergétique d'exploitations agricoles. Econ Rural 16-27 ST-Développement durable et analyse énerg. https://doi.org/10.3406/ecoru.1999.5096

Risoud B, Chopinet B (1999) Efficacité énergétique et diversité des systèmes de production agricole - application à des exploitations bourguignonnes. EAT, IRSTEA p:17-25

Rodríguez-Ortega T, Bernués A, Olaizola AMM, Brown MTT (2017) Does intensification result in higher efficiency and sustainability? An emergy analysis of Mediterranean sheep-crop farming systems. J Clean Prod 144:171-179. https://doi.org/10.1016/j.jclepro.2016.12. 089

Rufino MC, Tittonell P, Reidsma P et al (2009) Network analysis of N flows and food self-sufficiency-a comparative study of croplivestock systems of the highlands of east and southern Africa. Nutr Cycl Agroecosystems 85:169-186. https://doi.org/10.1007/ s10705-009-9256-9

Jorgensen SE (2006) Eco-exergy as sustainability. Witpress

Sciubba E (2019) Exergy-based ecological indicators: from thermoeconomics to cumulative exergy consumption to thermo- 
ecological cost and extended exergy accounting. Energy 168:462476. https://doi.org/10.1016/j.energy.2018.11.101

Sciubba E (2001) Beyond thermoeconomics? The concept of extended exergy accounting and its application to the analysis and design of thermal systems. Exergy, An Int J 1:68-84. https://doi.org/10.1016/ s1164-0235(01)00012-7

Sefeedpari P, Ghahderijani M, Pishgar-Komleh SH (2013) Assessment the effect of wheat farm sizes on energy consumption and $\mathrm{CO}_{2}$ emission. J Renew Sustain Energy 5:023131. https://doi.org/10. $1063 / 1.4800207$

Sefeedpari P, Rafiee S, Akram A, Komleh SHP (2014a) Modeling output energy based on fossil fuels and electricity energy consumption on dairy farms of Iran: application of adaptive neural-fuzzy inference system technique. Comput Electron Agric 109:80-85. https://doi. org/10.1016/j.compag.2014.09.010

Sefeedpari P, Shokoohi Z, Behzadifar Y (2014b) Energy use and carbon dioxide emission analysis in sugarcane farms: a survey on HaftTappeh Sugarcane Agro-Industrial Company in Iran. J Clean Prod 83:212-219. https://doi.org/10.1016/j.jclepro.2014.07.048

Shamshirband S, Khoshnevisan B, Yousefi M et al (2015) A multiobjective evolutionary algorithm for energy management of agricultural systems - a case study in Iran. Renew Sust Energ Rev 44:457465. https://doi.org/10.1016/j.rser.2014.12.038

Singh H, Mishra D, Nahar N. (2002) Energy use pattern in production agriculture of a typical village in arid zone, India - part I. Energy Convers Manag 43:2275-2286. https://doi.org/10.1016/S01968904(01)00161-3

Singh H, Mishra D, Nahar N (2004) Energy use pattern in production agriculture of a typical village in arid zone-part III. Energy Convers Manag 45:2453-2472. https://doi.org/10.1016/j. enconman.2003.11.014

Singh S, Mittal JP, Singh MP, Bakhshi R (1988) Energy-use patterns under various farming systems in Punjab. Appl Energy 30:261268. https://doi.org/10.1016/0306-2619(88)90013-X

Smith LG, Williams AG, Pearce BD (2015) The energy efficiency of organic agriculture: a review. Renew Agric Food Syst 30:280 301. https://doi.org/10.1017/S1742170513000471

Soni P, Taewichit C, Salokhe VM (2013) Energy consumption and CO2 emissions in rainfed agricultural production systems of Northeast Thailand. Agric Syst 116:25-36. https://doi.org/10.1016/j.agsy. 2012.12.006

Soto D, Infante-Amate J, Guzmán GI, Cid A, Aguilera E, García R, González de Molina M (2016) The social metabolism of biomass in Spain, 1900-2008: from food to feed-oriented changes in the agro-ecosystems. Ecol Econ 128:130-138. https://doi.org/10.1016/ j.ecolecon.2016.04.017

Stocker TF [ed. (2014) Climate change 2013: the physical science basis: working group. Fifth Assess Rep Intergov Panel Clim Chang 5

Szargut J (2005) Exergy analysis. Mag Polish Acad Sci 3:31-33

Taghizadeh-Hesary F, Rasoulinezhad E, Yoshino N (2019) Energy and food security: linkages through price volatility. Energy Policy 128: 796-806. https://doi.org/10.1016/j.enpol.2018.12.043

Tello E, Galán E, Cunfer G, et al (2015) A proposal for a workable analysis of Energy Return On Investment (EROI) in agroecosystems. Part I: Analytical approach. Vienna

Tello E, Galán E, Sacristán V et al (2016) Opening the black box of energy throughputs in farm systems: a decomposition analysis between the energy returns to external inputs, internal biomass reuses and total inputs consumed (the Vallès County, Catalonia, c.1860 and 1999). Ecol Econ 121:160-174. https://doi.org/10.1016/j.ecolecon. 2015.11.012

Tello E, González de Molina M (2017) Methodological challenges and general criteria for assessing and designing local sustainable agrifood systems: a socio-ecological approach at landscape level. In: Fralvnková E, Haas W, Singh SJ (eds) Socio-metabolic perspectives on the sustainability of local food systems: insights for science, policy and practice,Springer International Publishing, Cham, pp $27-67$

Tilman D (1999) Global environmental impacts of agricultural expansion: the need for sustainable and efficient practices. Proc Natl Acad Sci U S A 96:5995-6000. https://doi.org/10.1073/pnas.96. 11.5995

Tilman D, Cassman KG, Matson PA et al (2002) Agricultural sustainability and intensive production practices. Nature 418:671-677. https://doi.org/10.1038/nature01014

Tilman D, Socolow R, Foley JA, et al (2009) Beneficial biofuels - the food, energy, and environment trilemma. Science (80- ) 325:270 271. https://doi.org/10.1126/science.1177970

Todde G, Murgia L, Caria M, Pazzona A (2018a) A comprehensive energy analysis and related carbon footprint of dairy farms, part 1 : direct energy requirements. Energies 11:451. https://doi.org/10. 3390/en11020451

Todde G, Murgia L, Caria M, Pazzona A (2018b) A comprehensive energy analysis and related carbon footprint of dairy farms, part 2: investigation and modeling of indirect energy requirements. Energies 11:463. https://doi.org/10.3390/en11020463

Tripathi R, Sah V (2001) Material and energy flows in high-hill, mid-hill and valley farming systems of Garhwal Himalaya. Agric Ecosyst Environ 86:75-91. https://doi.org/10.1016/S0167-8809(00)00270$\mathrm{X}$

Upton J, Humphreys J, Groot Koerkamp PWG et al (2013) Energy demand on dairy farms in Ireland. J Dairy Sci 96:6489-6498. https:// doi.org/10.3168/jds.2013-6874

Utlu Z, Hepbasli A (2006) Assessment of the energy and exergy utilization efficiencies in the Turkish agricultural sector. Int J Energy Res 30:659-670. https://doi.org/10.1002/er.1176

Uzal S (2013) Comparison of the energy efficiency of dairy production farms using different housing systems. Environ Prog Sustain Energy 32:1202-1208. https://doi.org/10.1002/ep.11727

Veiga JPS, Romanelli TL, Gimenez LM et al (2015) Energy embodiment in Brazilian agriculture: an overview of 23 crops. Sci Agric 72:471477. https://doi.org/10.1590/0103-9016-2015-0188

Veysset P, Lherm M, Bebin D et al (2010) Energy consumption, greenhouse gas emissions and economic performance assessments in French Charolais suckler cattle farms: model-based analysis and forecasts. Agric Syst 103:41-50. https://doi.org/10.1016/j.agsy. 2009.08.005

Vigne M, Benagabou I, Faverdin P et al (2014) Fossil energy efficiency assessment of livestock systems in West Africa: methodological adaptations and perspectives. INRA Prod Anim 27:369-379

Vigne M, Martin O, Faverdin P, Peyraud J-L (2012a) Comparative uncertainty analysis of energy coefficients in energy analysis of dairy farms from two French territories. J Clean Prod 37:185-191. https:// doi.org/10.1016/j.jclepro.2012.07.005

Vigne M, Peyraud J-L, Lecomte P, Corson MS, Wilfart A (2013a) Emergy evaluation of contrasting dairy systems at multiple levels. J Environ Manag 129:44-53. https://doi.org/10.1016/j.jenvman. 2013.05.015

Vigne M, Vayssières J, Lecomte P, Peyraud J-L (2012b) Evaluating the ability of current energy use assessment methods to study contrasting livestock production systems. J Environ Manag 112:199-212. https://doi.org/10.1016/j.jenvman.2012.07.017

Vigne M, Vayssières J, Lecomte P, Peyraud J-L (2013b) Pluri-energy analysis of livestock systems - a comparison of dairy systems in different territories. J Environ Manag 126:44-54. https://doi.org/10. 1016/j.jenvman.2013.04.003

Wang X, Chen Y, Sui P et al (2014) Emergy analysis of grain production systems on large-scale farms in the North China Plain based on LCA. Agric Syst 128:66-78. https://doi.org/10.1016/j.agsy.2014. 03.005

Wang X, Dadouma A, Chen Y et al (2015) Sustainability evaluation of the large-scale pig farming system in North China: an emergy 
analysis based on life cycle assessment. J Clean Prod 102:144-164. https://doi.org/10.1016/j.jclepro.2015.04.071

Wrigley EA (2013) Energy and the English industrial revolution. Philos Trans R Soc A Math Phys Eng Sci 371:20110568. https://doi.org/ 10.1098/rsta.2011.0568

Wu JY, Martinov M, Sardo VI (2011) Human labour and green manure, two overlooked factors for energy analysis in agriculture. In: Lichtfouse E (ed) Genetics, biofuels and local farming system, Springer, pp 215-229

Wu X, Wu F, Tong X, Jiang B (2013) Emergy-based sustainability assessment of an integrated production system of cattle, biogas, and greenhouse vegetables: insight into the comprehensive utilization of wastes on a large-scale farm in Northwest China. Ecol Eng 61:335344. https://doi.org/10.1016/j.ecoleng.2013.09.060

Yi T, Xiang P (2016) Emergy analysis of paddy farming in Hunan Province, China: a new perspective on sustainable development of agriculture. J Integr Agric 15:2426-2436. https://doi.org/10.1016/ S2095-3119(16)61375-8

Zangeneh M, Omid M, Akram A (2010) A comparative study on energy use and cost analysis of potato production under different farming technologies in Hamadan province of Iran. Energy 35:2927-2933. https://doi.org/10.1016/j.energy.2010.03.024

Zegada-Lizarazu W, Matteucci D, Monti A (2010) Critical review on energy balance of agricultural systems. Biofuels Bioprod Biorefin 4:423-446. https://doi.org/10.1002/bbb.227

Zhang G, Long W (2010) A key review on emergy analysis and assessment of biomass resources for a sustainable future. Energy Policy 38:2948-2955. https://doi.org/10.1016/j.enpol.2010.01.032

Zhang L-X, Hu Q-H, Wang C-B (2013) Emergy evaluation of environmental sustainability of poultry farming that produces products with organic claims on the outskirts of mega-cities in China. Ecol Eng 54: 128-135. https://doi.org/10.1016/j.ecoleng.2013.01.030

Zisopoulos FK, Overmars L, van der Goot AJ (2017) A conceptual exergy-based framework for assessing, monitoring, and designing a resource efficient agri-food sector. J Clean Prod 158:38-50. https://doi.org/10.1016/j.jclepro.2017.04.160

Publisher's note Springer Nature remains neutral with regard to jurisdictional claims in published maps and institutional affiliations. 